تأثير بعض المبيدات الكيميائية المستخدمة لمكافحة الافات الزراعية على أعداد الإحياء الجهرية في التربة

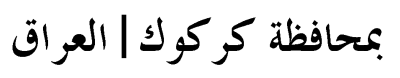

ץ- تقليل تأثير المبيدات على أعداد الأحياء المهجرية في التربة بإضافة المادة العضوية تحت ظروف مختبريه

$$
\text { دلشاد رسول عزيز }
$$

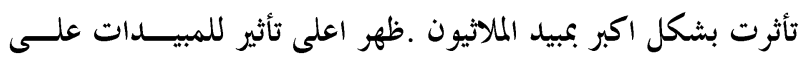

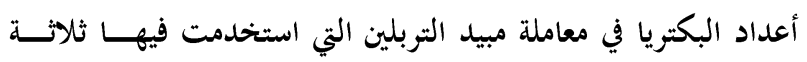

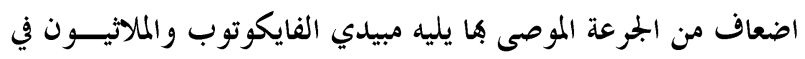

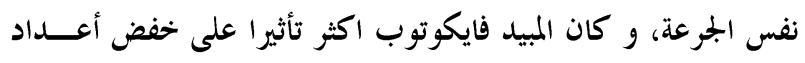

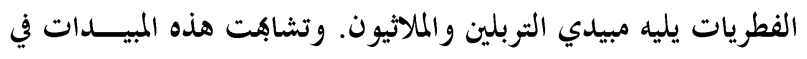
تأثير اتها على اعداد الأكتينو مايسيتات. كما دلت النتائج على أن إضافة المادة العضوية المى التربة قد ادت الى زيادة في اعداد احياء التربة الجهرية كما تقلل من التأثير المثبط

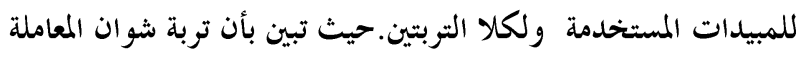

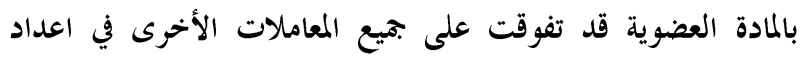

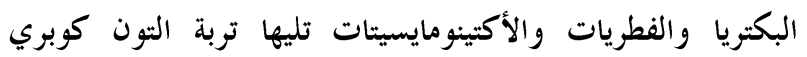
المعاملة بالمادة العضوية ومن ثم تليها تربة شوان غير المبات المعاملة بالمادة

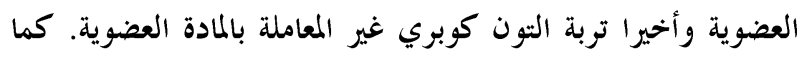

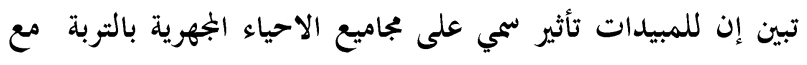

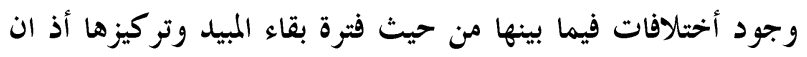

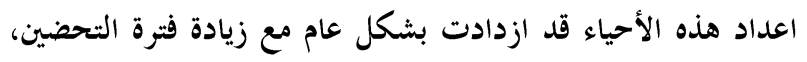

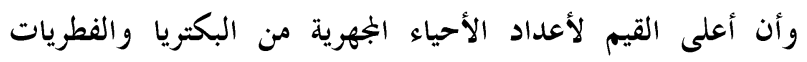

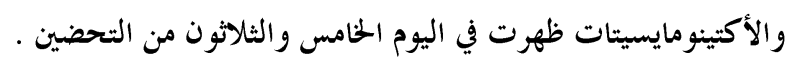

\section{المقدمة و المشكلة البحثية}

أدى الاستخدام المفرط للمبيدات الكيميائية أثناء عمليات الخحمة

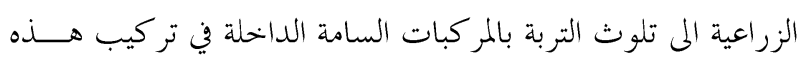
المبيدات، فقد تصبح هذه المبيدات مصدرا لتلوث المنتوجات الزراعية

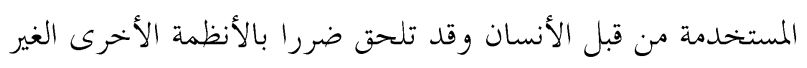

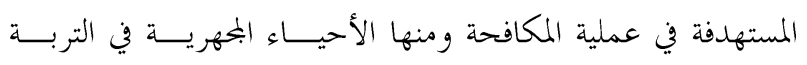

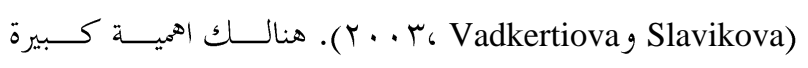

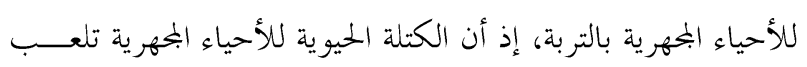

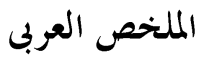

أدى الاستخدام المفرط للمبيدات الكيميائية أثناء عمليات الحخدمة

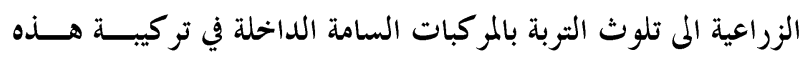

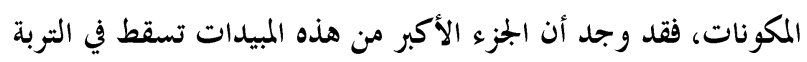

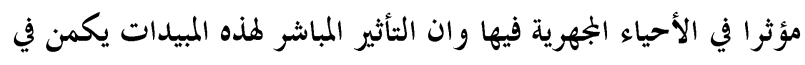

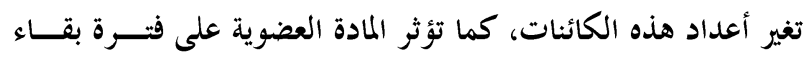

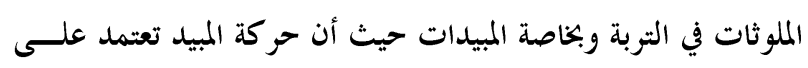
تفاعله مع حبيبات الثربة والمادة العضوية من خلال عمليتي الادمصاص وعكسها.

يهدف البحث إلى دراسة تأثير المبيدات الكيميائية على أعسـداد

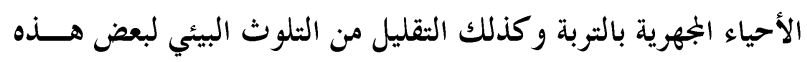

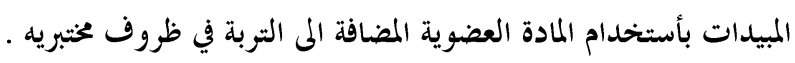

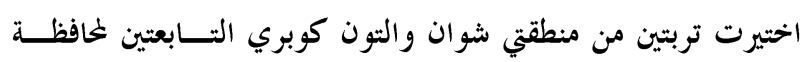

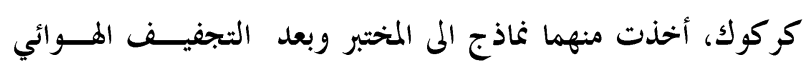

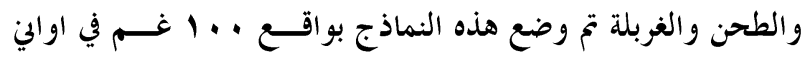

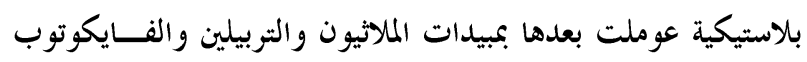

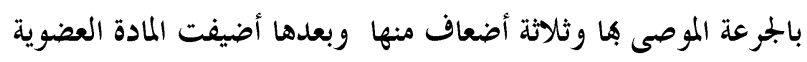

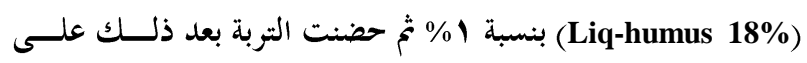
درجة حرارة 28 × 2 درجة مئوية مع حفظ الرطوبة في مستوى 70

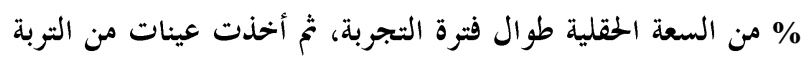

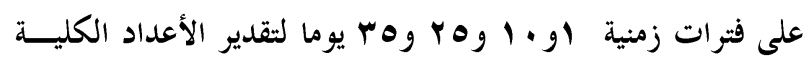

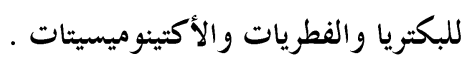

دلت النتائج على إن إضافة المبيدات بشكل عام قد تــؤدي المى لئل

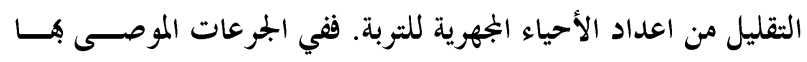

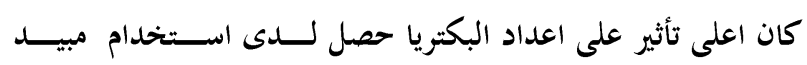

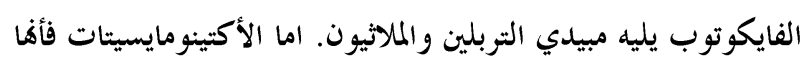

أستاذ مساعد-كلية الزراعة- جامعة كركوك - العراق

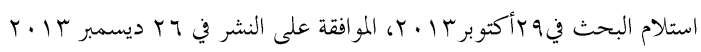




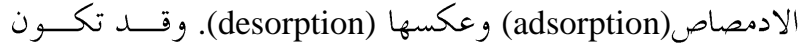

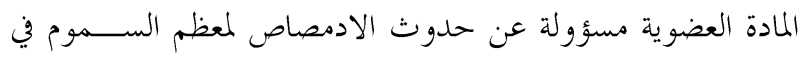

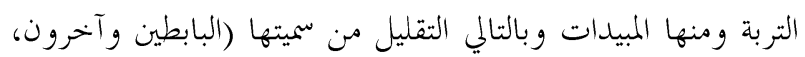

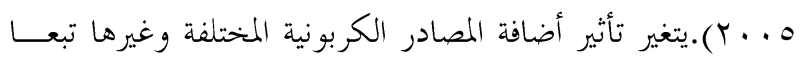

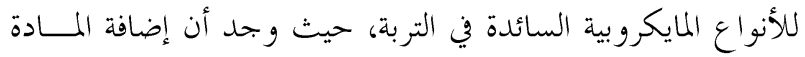

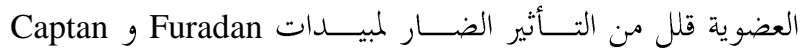

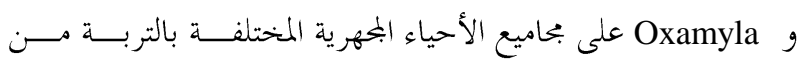

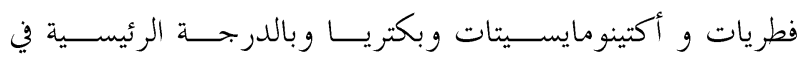
التركيزات العالية منها (El-Shahawy و آخرون، 1919 (1). تبينت من خلال دراسات عدة أن إضافة بعض المبيدات تعمـلـ

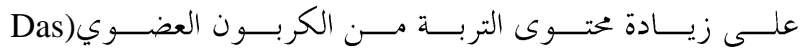
. (2000، Mukherjee,

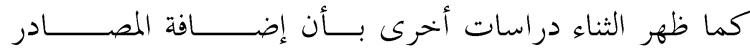
الكربونية مــثل الــجلو كوز تــبطء من معدل التحلل الحيوي لمبيد الكلوربسيرفوس(Chlorpyrifos) بواسطة بكتيريا Enterobacter)

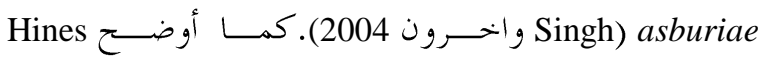
وآخرون (1998) أن تحلل ميثايل بروميــد (Methyl Bromide)

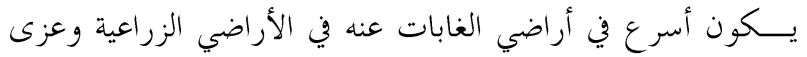
السبب في ذلك إلى احتواء أراضي الغابات على كمية أكبر من المادة العضوية مقارنة بالأراضي الزراعية.

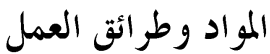

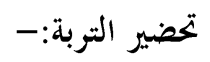

تم استخدام نوعين من التربة، الأولى تربة مزيجية غرينيــة مـــن

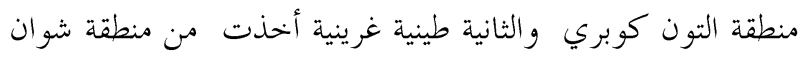
التابعتين لمحافظة كر كوك أخذت نماذج العينات من الطبقة السطحية (صفر - 10 سم) جمعت العينات في أكياس بلاسـتيكية نظيفــة.

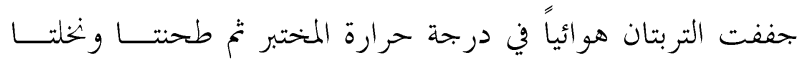

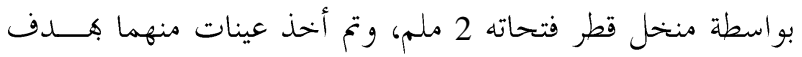

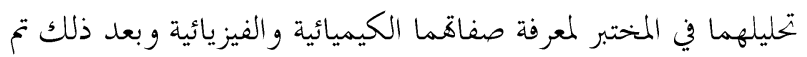
توزيع التربة ولكلا المنطقتين بواقع · . اغم في علب بلاستيكية

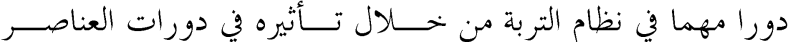
الغذائية وعمليات الهدم والتحلل التي تحصل بالتربة والعمليات الحيوية

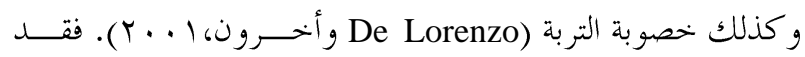
وجد أن الجزء الأكبر من هذه المبيدات تسقط في التربة مـــؤثرةً في الأحياء المجهرية، وان التأثير المباشر لهذه المبيدات على تلك الك الأحيــاء

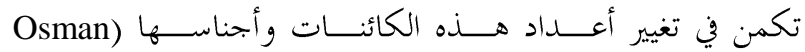

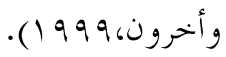

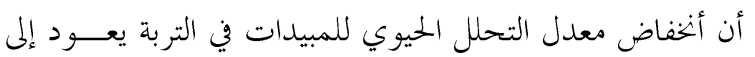

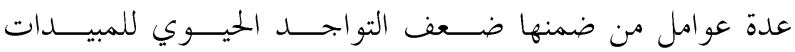

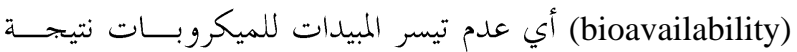
لادمصاصها على غرويات التربة والمادة العضوية وبالتالي احتمـــال زيادة ظهور المبيدات باستمرار في المياه الجوفية والســطـية (Park)

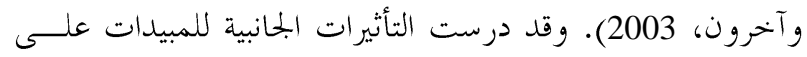

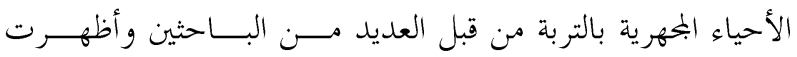

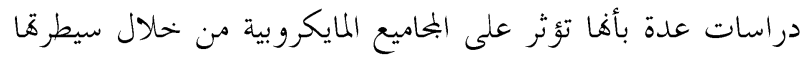

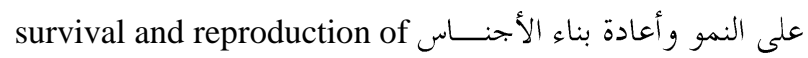

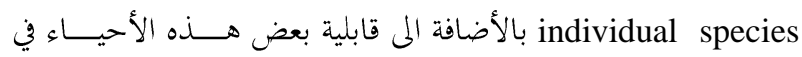
تعطيم هذه المبيدات في التربة(De Lorenzo و آخرون، ال . ب). و و

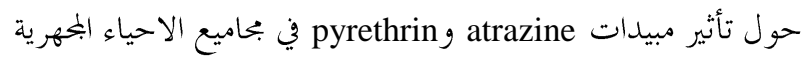

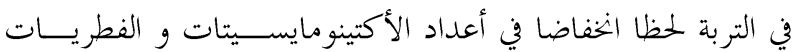

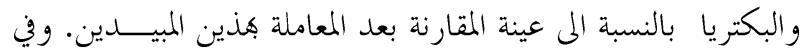

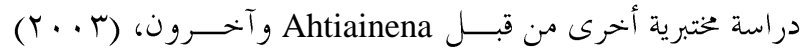

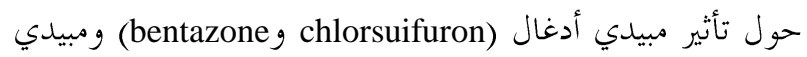
الفطريــات (propiconazolr و carboxin-imazalin ) ومبيــــي

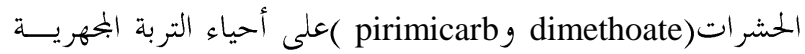

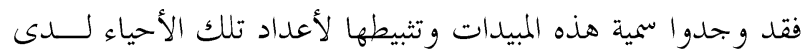
استخدام الجرعات العالية فقط.

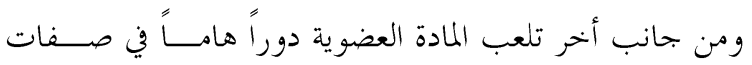
التربة الفيزيائية والكيميائية والحيوية، كما تؤثر المادة العضوية في فترة

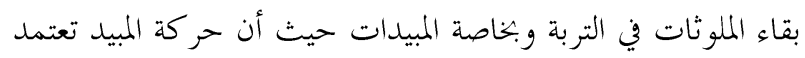
على تفاعله مع حبيبات التربة والمادة العضوية به من خلال عملــيتي 


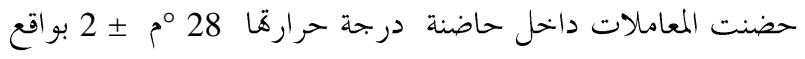

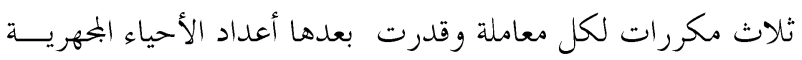

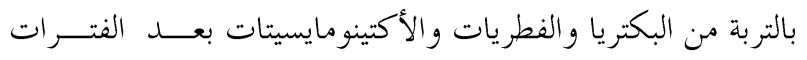

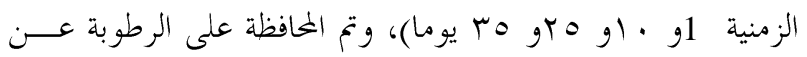
طريق قياس فرق الوزن وإضافة ماء مقطر معقم. المبيدات المستخدمة في التجربة:-

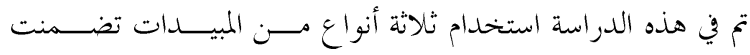
مبيدات الحشرات و الأدغال و الفطريات و كالأي:--

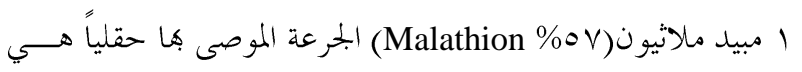

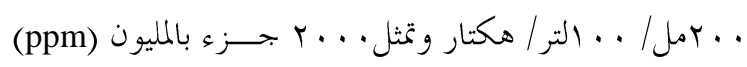

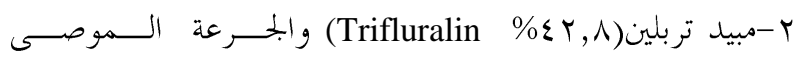

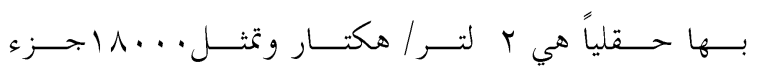
بالمليون(p).

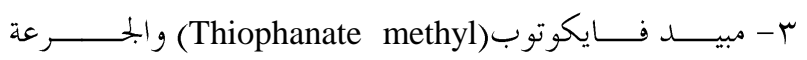

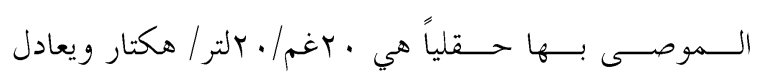

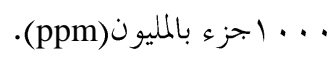

وقد استخدمت المبيدات في هذه الدراسة بتر كيزين هما الجحرعسـة الموصي هـا حقليا وتلاثة أضعاف منها. تقديرات أعداد الأحياء الجهرية:-

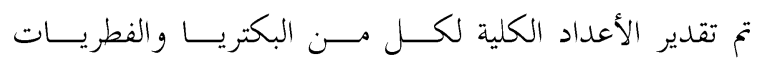

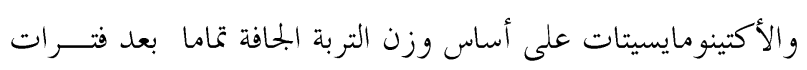
التحضين المذكورة و كالأتي:

\section{تحضير التخافيف المتسلسلة:}

تم تخضير تخافيف متسلسلة للترب الملوثة بكل نوع من المبيدات

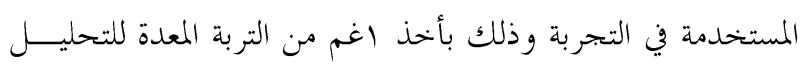

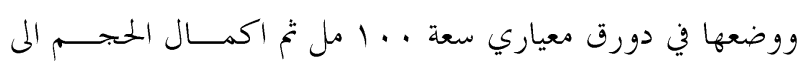

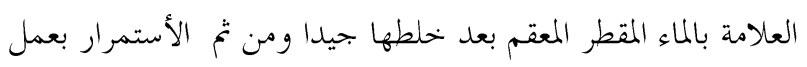
التخافيف للحصول على التخافيف المطلوبة لكل نوع من الأحيـاء البحهرية.
مثقبة من الأسفل ومزودة بأوراق ترشيح لمنع فقدان التربــة مــن الأسفل لتمثل كل علبة وحدة تجريبية و كالأتي: - تربة معاملة بالجرعة الموصي هما من مبيد ملاثيون T2 - م3 تربة معاملة بثلاثة أضعاف من الجرعة الموصي هـا من مبيــد ملاثيون - T4 تربة معاملة بالجرعة الموصي بها من مبيد تربلين

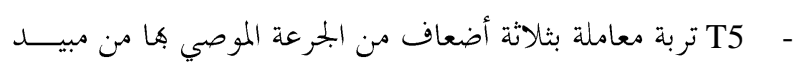
تربلين T6 - تربة معاملة بالجرعة الموصي هها من مبيد فايكوتوب

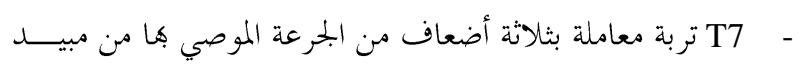

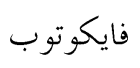
- T9 تربة معاملة بالجرعة الموصي بها من مبيد ملاثيون + 1 \% مادة عضوية

ملاثيون+ 1 1 \% مادة عضوية

T11 تربة معاملة بالجرعة الموصي بها من مبيد تربلين+ 1 \% مادة

$$
\text { عضوية }
$$

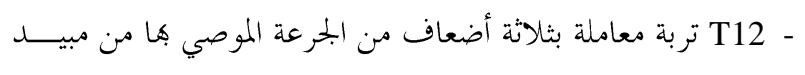

$$
\text { تربلين+ 1 } 1 \text { \% مادة عضوية }
$$

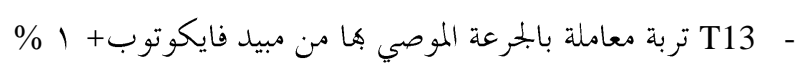

$$
\text { مادة عضوية }
$$

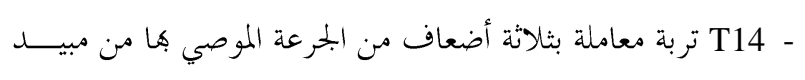

$$
\text { فايكوتوب+ 1 } 1 \text { \% مادة عضوية }
$$

حيث أضيفت المادة العضوية (Liq-humus 18\% ) بنسبة إ)

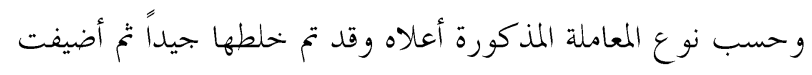

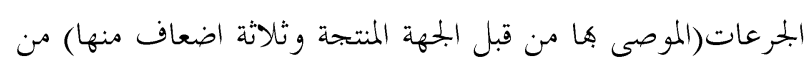

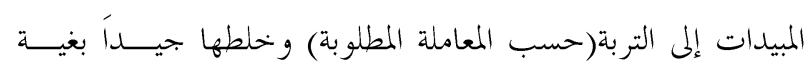

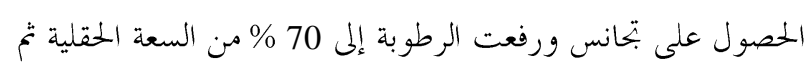


جدول ا ـ بعض الصفات الكيميائية والفيزيائية لترب الدراسة

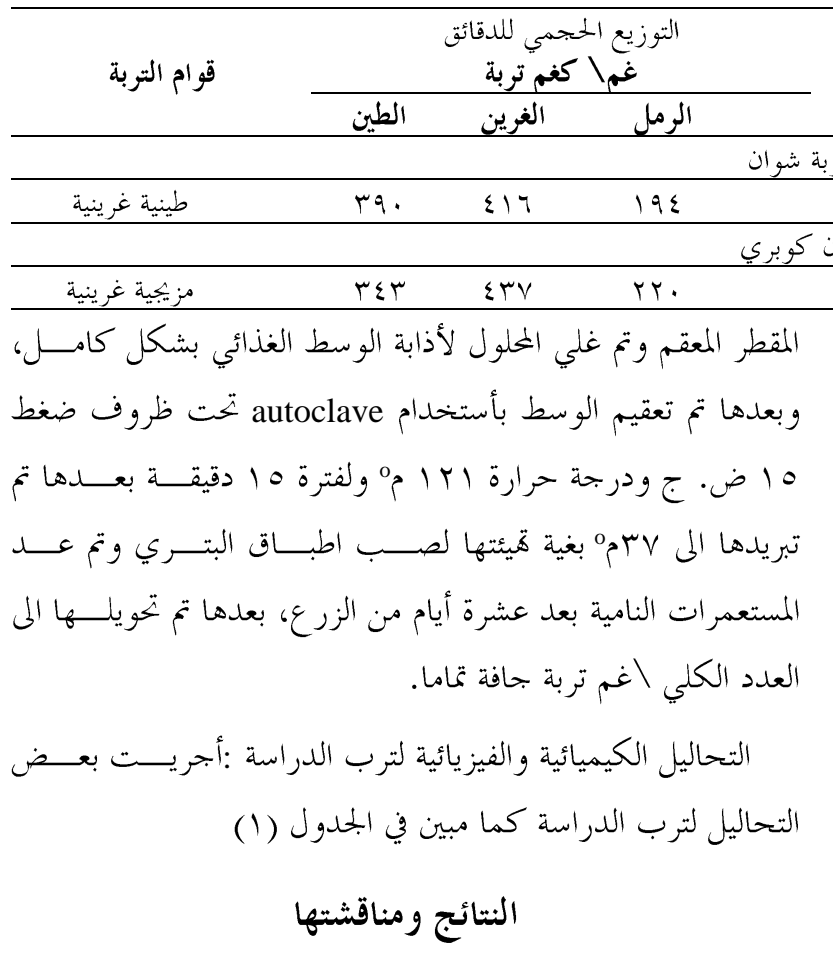

$$
\text { أولا :- تربة شوان }
$$

1- أعداد البكتريا الكلية:

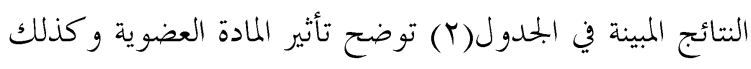

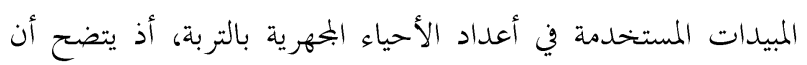

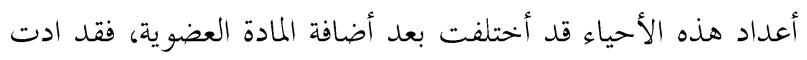

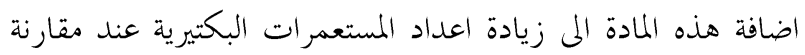
المعاملتين T1 و T8 ولمجيع فترات التحضين.

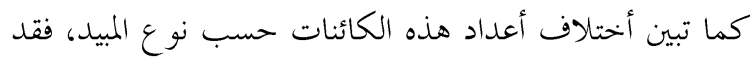

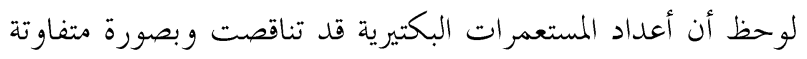

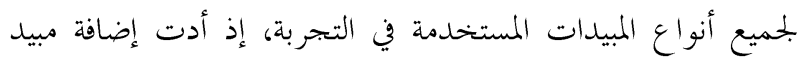

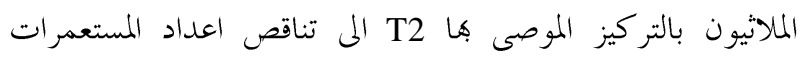

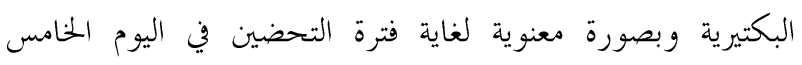

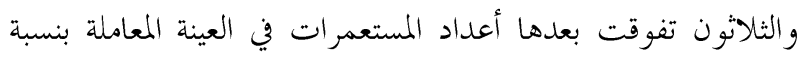

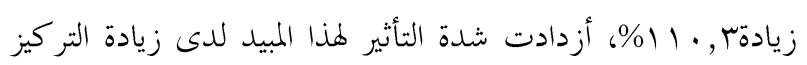
المستخدم الى ثلاثة أضعاف

\begin{tabular}{|c|c|c|c|}
\hline غلكماكية الكاتي & غماكغيم تربة & الكهربائيل التمبر & pH \\
\hline
\end{tabular}
لديسمز امتر

10,1 $\cdot, r q \quad v, o$

rVT

Y تربة

11,0

$\cdot, r q$

V,T

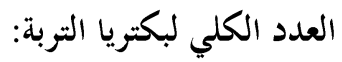

وضع ^ץ غم من الوسط الغذائي nutrient agar (محضرة مسـن

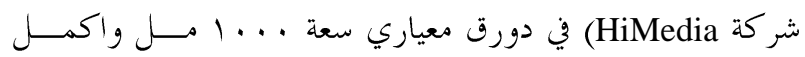

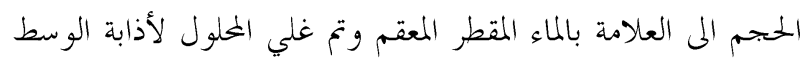
الغذائي بشكل كامل وبعدها تم تعقيم الوسط بأستخدام autoclave

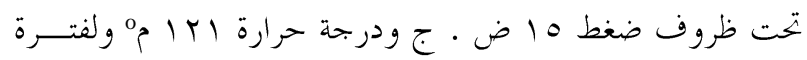

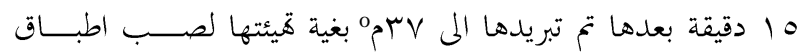

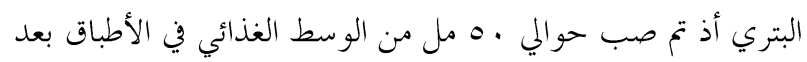

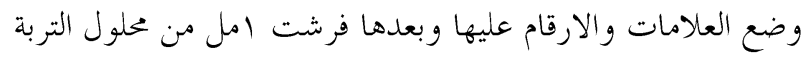

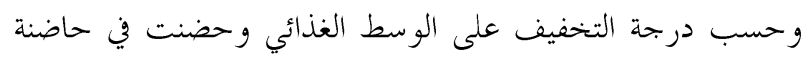
درجة حرارةتا 28 د 2 مْ وتم عد المستعمرات النامية بعد ســبعة

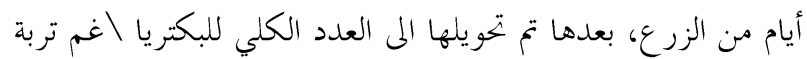

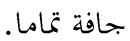
العدد الكلي لفطريات التربة: - الع

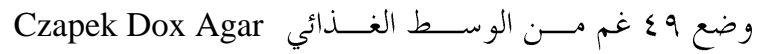

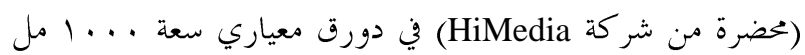

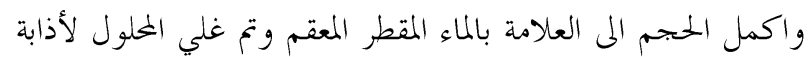

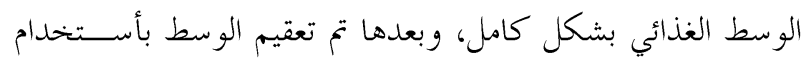
autoclave

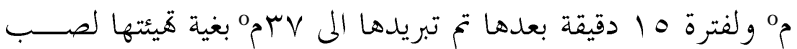

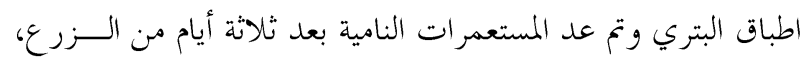
بعدها تم تحويلها الم العدد الكلي لغم تربة جافة تماما. العدد الكلي للأكتينو مايسيتات: وضع V و غم من الوسط الغذائي (starch ammonium agar في دورق معياري سعة ... . إمل وأكمل الحجم الى العلامة بالماء 


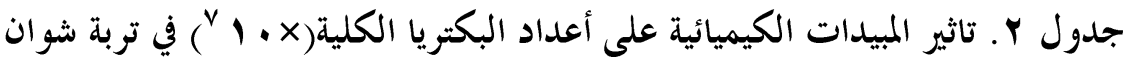

\begin{tabular}{|c|c|c|c|c|c|c|c|c|}
\hline أو الزتبيط & وثلاثون & أو الزتبيط & وعشرون & أو الزيادة & عشرة ايام & أو الثبيط \%ادة & ويوم & لمعاملات \\
\hline- & 37.38 & - & 34.63 & - & 12.22 & - & 9.24 & T1 المقارنة ا T1 \\
\hline $110.3+$ & 41.24 & $18.5-$ & 28.22 & $13.7-$ & 10.54 & $20.6-$ & 7.33 & ملاثيون \1 \\
\hline $7.7-$ & 34.47 & $31.4-$ & 23.74 & $39.5-$ & 7.39 & $36.5-$ & 5.86 & ملاثيون\ب \\
\hline 13.6- & 32.28 & $11.2-$ & 30.74 & $4.9-$ & 11.62 & $15.4-$ & 7.81 & تربلين\| \\
\hline $33.9-$ & 24.69 & $47.6-$ & 18.12 & $41.8-$ & 7.1 & $52.5-$ & 4.38 & تربلين Y \\
\hline 19.5- & 30.08 & $24.5-$ & 26.12 & $19.2-$ & 9.87 & $30.5-$ & 6.38 & فايكوتوب|| \\
\hline $13.12-$ & 24.26 & $26.3-$ & 25.5 & $23.5-$ & 9.34 & 56.4- & 4.02 & فايكوتوباب \\
\hline- & 89.37 & - & 77.51 & - & 21.41 & - & 11.58 & المقارنة Y \\
\hline $5.2-$ & 84.72 & 9.8- & 69.81 & $19.8-$ & 17.16 & $28.9-$ & 8.23 & ملاثيون\س \\
\hline $21.5-$ & 70.14 & $23.6-$ & 59.17 & $29.6-$ & 15.06 & $45.0-$ & 6.36 & ملاثيون\ع \\
\hline $23.5-$ & 68.28 & $8.1-$ & 71.16 & 4.9- & 20.36 & $14.5-$ & 9.89 & تربلين\ب \\
\hline $41.2-$ & 52.52 & $23.5-$ & 59.24 & $37.3-$ & 13.42 & $31.6-$ & 7.91 & تربلين\ع \\
\hline $32.5-$ & 60.28 & $15.5-$ & 65.45 & $17.2-$ & 17.72 & $22.1-$ & 9.01 & فايكوتوب\ب \\
\hline \multirow[t]{2}{*}{ 49.4- } & 45.22 & $37.5-$ & 48.41 & 9.6- & 19.35 & $55.7-$ & 5.12 & فايكوتوب\ي T14 \\
\hline & 5.325 & & 5.13 & & 2.068 & & 0.808 & LSD 0.05 \\
\hline
\end{tabular}

*علامة (+) تدل على زيادة العدد بعد إضافة المبيد أما العلامة (- ) تدل على نقصه

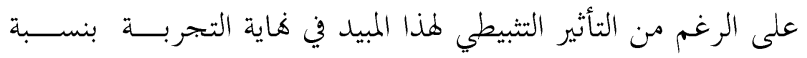

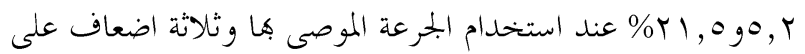
التوالي (المعاملتين T10وT10) الا انه ادت في الوقت ذاته المى زيــادة اعداد هذه المستعمرات لدى مقارنتهما بالمعاملتين T2 وT3 وهكذا

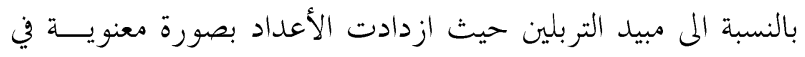

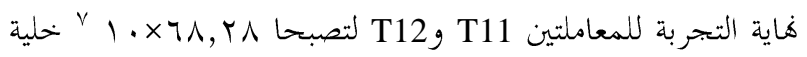

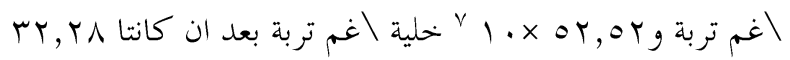

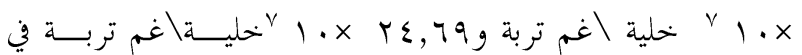
المعاملتين T4 وT5 الغير المعاملتين بالمادة العضوية، وتشاهت الحالة

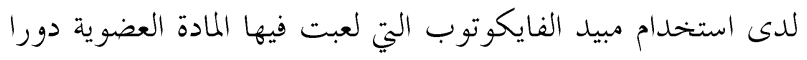
في زيادة اعداد المستعمرات بصورة معنوية لدى مقارنة المعــاملتين T13 وT14 مع المعاملتين T6 و T7 على التو الي.

\section{ب- ب اعداد الفطريات الكلية:}

للدى ملاحظة الجلدول (ب) يتضح أن أضافة المــادة العضـــوية

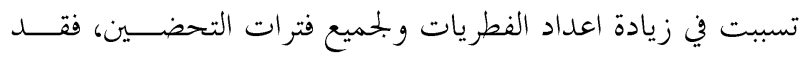

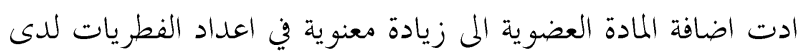
مقارنة عينات المقارنة T1 وT8 مع بعضها البعض ولجميع فتــرات

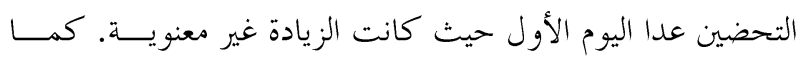

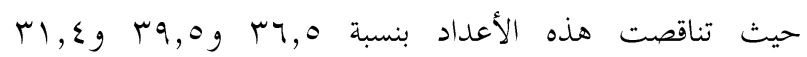

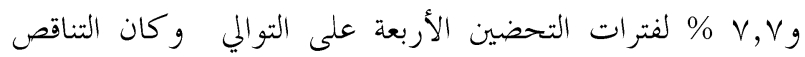

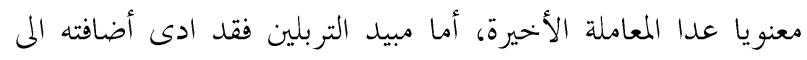
تناقص وتثبيط أعداد هذه الكائنات في جميع فترات التحيرهات التحضين وكانت معنوية فقط في اليوم الأول، في حين كان التناقص معنويا

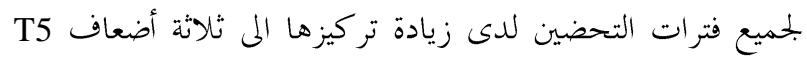

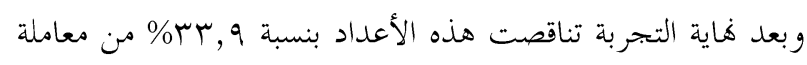

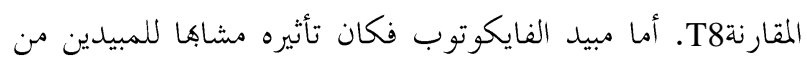
حيث تأثيره في خفض أعداد المستعمرات البكتيرية و كان هذا التأثير

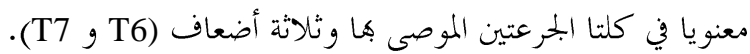
أظهرت النتائج في الجدول (r) أيضا ان أضافة المادة العضوية قد

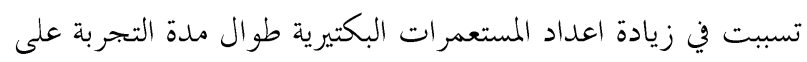

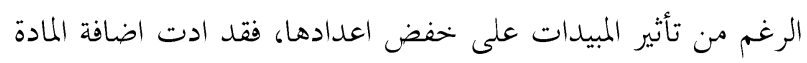

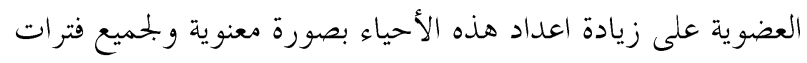

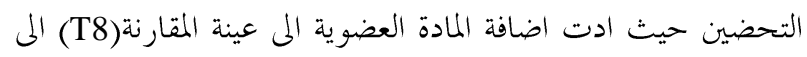

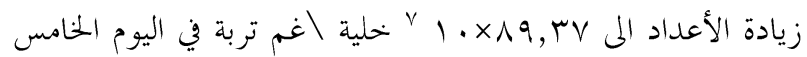

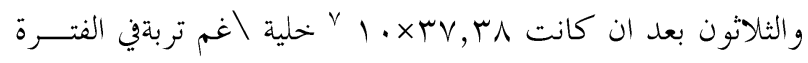
ذاها عند عدم اضافة المادة العضوية(T1). وفي معاملة الملاثيون فانه 


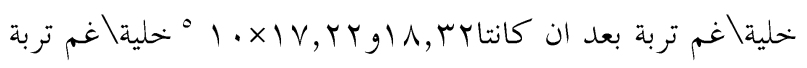
في T2 و T3 الغيرمعاملتين بالمادة العضوية، و وتشابهت الحالة لــــى

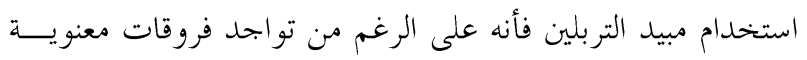

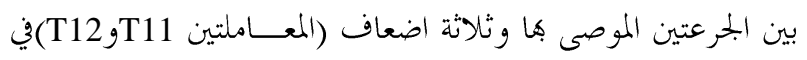
اعداد الفطريات ولكن. هذه الأعداد كانت اكبر للى مقارنتـــما

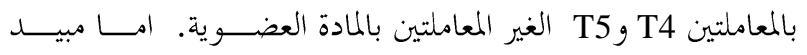

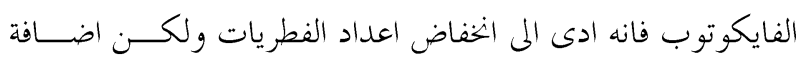

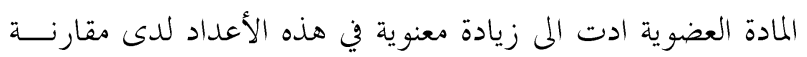
المعاملتين T13 T14 مع المعاملتين (T6 و T76) على التو المي.

\section{ب- أعداد الأكتينومايسيتات الكلية: - ب أع}

يتضح من نتائج الجلدول(ع) التأثير الواضح لأستخدام هــــه المبيدات على اعداد أكتينومايسيتات التربة ، فقد ادى استخدام مبيد الملاثيون الى انخفاض معنوي في اعداد هذه الاحياء ولكال الجرعتين

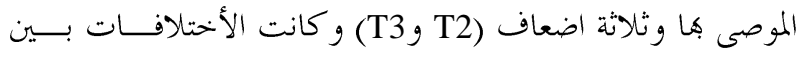
الجرعتين غير معنوية طوال فترة التجربة اذ بلغت القدرة التبيطية لهذا

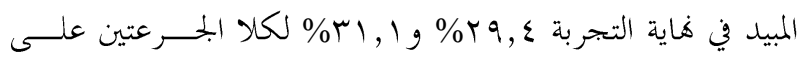
التو الي
دلت النتائج بأن اضافة المبيدات لها اثتر تثبطيطي في هــــه الأعــــاد

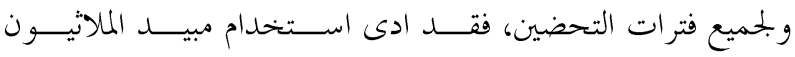
وبالجرعتين الموصى هها وتلاثة اضعاف الى الخفاض اعداد الفطريات

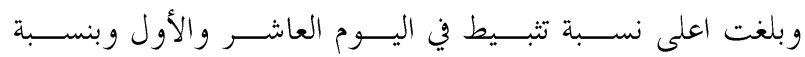
T, ب rو r, • ع\% لكال الجرعتين على التوالي. ولكن في حالة استخدام مبيد التربلين فان أعلى نسبة للتثبــيط ظهرت في اليوم العاشر والخامس عشر للجرعتين الموصى بها وثلانة

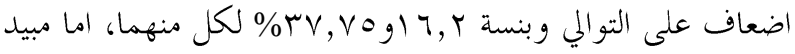
الفايكوتوب فكان الأثر التثبيطي له اعلى من المبيدين الأخربين حيث

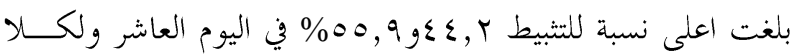
الجرعتين الموصى بها وثلاثة اضعاف على التوالي. بات واضحا من النتائج بأن اضافة المادة العضوية الى المعاملات ادت الى زيادة معنوية في اعداد الفطريات على الرغم من اســتخدام المبيدات بكلا الجرعتين، وان اضافة المبيدات بجميع انواعها ادت الم لى خفض الأعداد لإلميع فترات التحضين، حيث ان الأستخدام المتزامن

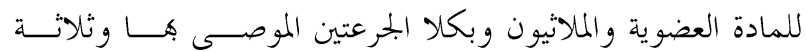
اضعاف(المعاملتين T10وT9) ادت الم زيادة اعداد هذه الكائنــات

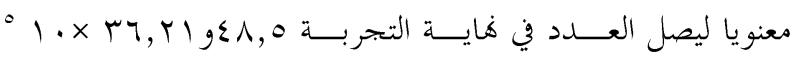

جدول س. تاثير المبيدات الكيميائية في أعداد الفطريات(× × ا م) في تربة شوان

\begin{tabular}{|c|c|c|c|c|c|c|c|c|c|}
\hline أو الزيادة & وثلاثون & أو الزيادة & وعشرون & 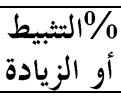 & عشرة ايام & ألثبيط الزيادة & يوم واحد & \multicolumn{2}{|c|}{ المعاملات } \\
\hline- & 21.96 & - & 12.52 & - & 7.37 & - & 4.56 & المقارنة| 1 & $\mathrm{~T} 1$ \\
\hline $16.5-$ & 18.32 & $12.8-$ & 10.91 & $23.6-$ & 5.63 & $15.3-$ & 3.86 & ملاثيون \1 & $\mathrm{T} 2$ \\
\hline $21.5-$ & 17.22 & $29.3-$ & 8.48 & $37.7-$ & 4.59 & $40.3-$ & 2.72 & ملاثيون\ب & $\mathrm{T} 3$ \\
\hline $6.9-$ & 20.44 & $9.7-$ & 11.3 & $16.2-$ & 6.17 & $10.0-$ & 4.1 & تربلين || & $\mathrm{T} 4$ \\
\hline $35.6-$ & 14.13 & $37.3-$ & 7.84 & $33.5-$ & 4.9 & 18.6- & 3.71 & تربلين Y & $\mathrm{T} 5$ \\
\hline $15.5-$ & 18.54 & $25.0-$ & 9.39 & $44.2-$ & 4.11 & $32.0-$ & 3.1 & فايكوتوبال & T6 \\
\hline $41.6-$ & 12.82 & $40.3-$ & 7.47 & $55.9-$ & 3.25 & $43.2-$ & 2.59 & فايكوتوباب & $\mathrm{T} 7$ \\
\hline- & 43.16 & - & 26.42 & - & 10.74 & - & 5.13 & المقارنة\ب & T8 \\
\hline $112.3+$ & 48.5 & $23.8-$ & 20.11 & $32.7-$ & 7.22 & $15.3-$ & 4.34 & ملاثيون\r & $\mathrm{T} 9$ \\
\hline $16.1-$ & 36.21 & $38.2-$ & 16.32 & $43.3-$ & 6.08 & $32.9-$ & 3.44 & ملاثيون\ع & $\mathrm{T} 10$ \\
\hline $6.7-$ & 40.26 & $14.7-$ & 22.53 & 13.9- & 9.24 & $2.9-$ & 4.98 & تربلين\س & $\mathrm{T} 11$ \\
\hline $29.8-$ & 30.26 & $43.6-$ & 14.9 & $32.5-$ & 7.24 & $29.6-$ & 3.61 & تربلين\ع & $\mathrm{T} 12$ \\
\hline 20.9- & 34.13 & $20.0-$ & 21.12 & $48.2-$ & 5.56 & $25.5-$ & 3.82 & فايكوتوباس & $\mathrm{T} 13$ \\
\hline 19.9- & 34.53 & 20.74- & 20.94 & $63.9-$ & 3.87 & $47.3-$ & 2.7 & فايكوتوبل\ع & $\mathrm{T} 14$ \\
\hline & 1.124 & & 1.495 & & 0.662 & & 0.649 & & 0.05 \\
\hline
\end{tabular}




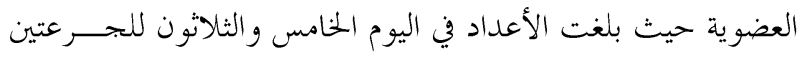

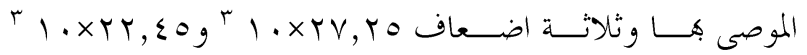

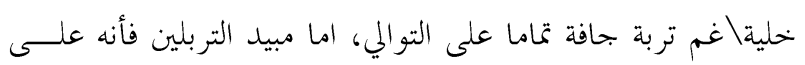
الرغم من تزايد اعداد الأكتينومايسيتات في المعاملة T11 عن معاملة المقارنة لليومين الأول والعاشر من التحضين الا انه بصورة عامة ادى ترى

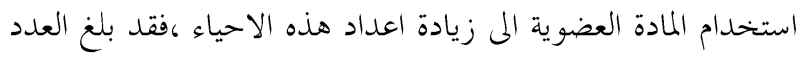

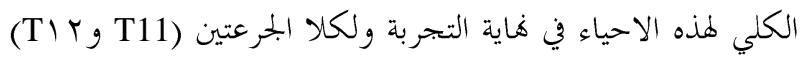

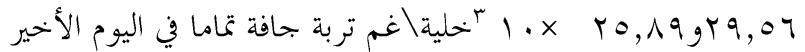

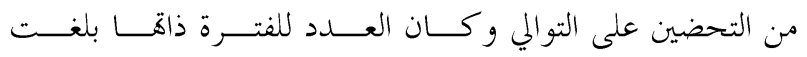

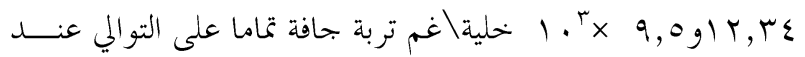

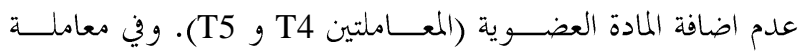
الفايكوتوب (T13 وT14) بلغ العدد النهائي في اليـوم الخـــامس

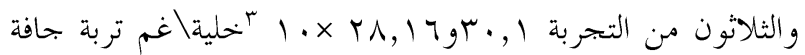

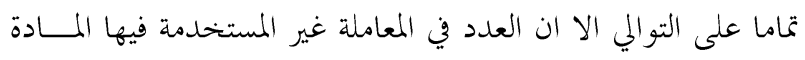

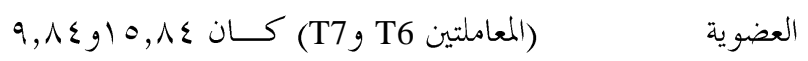

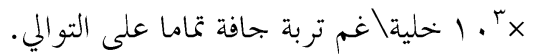

وكذلك مبيد التربلين فأنه ايضا ادى الى الخفاض معنــوي في

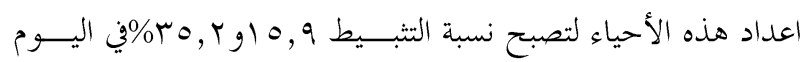

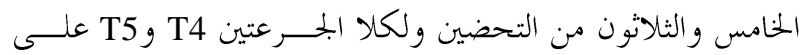

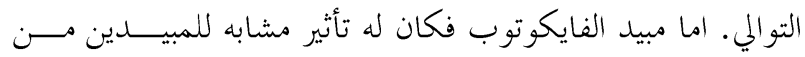

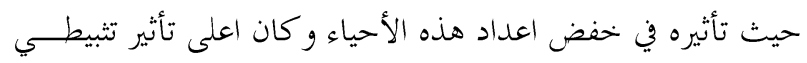

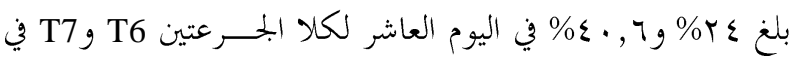

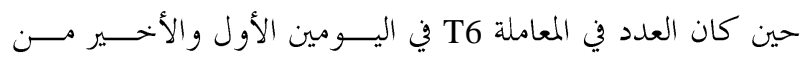

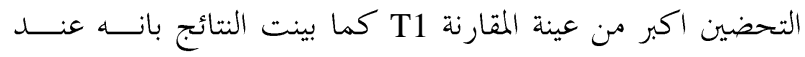
مقارنة المعاملتين T1 و T8 مع بعضهما فأن اضافة المادة العضــــينة

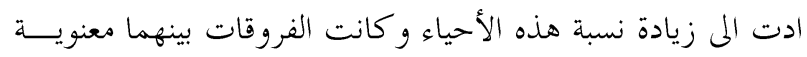

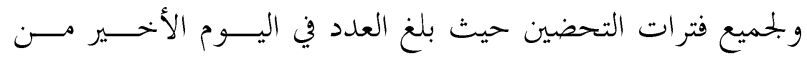

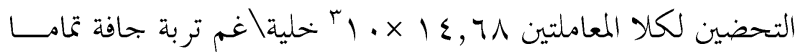

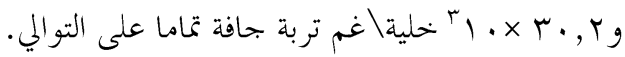
وقد وجد ان اضافة المادة العضوية ادت الى التقليل من تأثير هذه

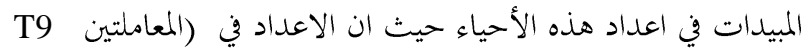
و T10) التي استخدمت فيها المـــادة العضــويةاكبر مــن اعــــاد

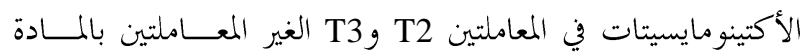

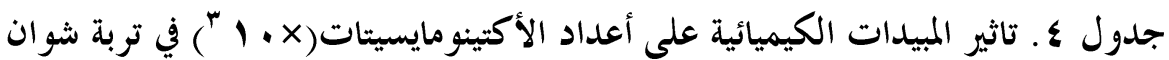

\begin{tabular}{|c|c|c|c|c|c|c|c|c|}
\hline أو التثبيط & وثلاثون & \% التئبيط أو & وعشرون & 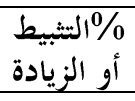 & عشرة & التبيط \%ادة أو & و يومد & المعاملات \\
\hline 0 & 14.68 & 0 & 8.52 & 0 & 4.94 & 0 & 2.76 & T1 المقارنة \1 \\
\hline 29.4- & 10.35 & $7.6-$ & 7.87 & $21.4-$ & 3.88 & $19.5-$ & 2.22 & مالثيون \1 \\
\hline $31.1-$ & 10.11 & $26.9-$ & 6.22 & $21.0-$ & 3.9 & $16.6-$ & 2.3 & ملاثيون\ب \\
\hline $15.9-$ & 12.34 & $4.9-$ & 8.1 & 17.4- & 4.08 & $115+$ & 3.18 & تربلين|| \\
\hline $35.2-$ & 9.5 & $42.2-$ & 4.92 & $34.0-$ & 3.26 & $23.1-$ & 2.12 & تربلين Y \\
\hline $107.9+$ & 15.84 & $6.5-$ & 7.96 & $24.0-$ & 3.75 & $102+$ & 2.82 & فايكوتوبال \\
\hline $32.9-$ & 9.84 & $32.3-$ & 5.76 & $40.6-$ & 2.93 & $22.1-$ & 2.15 & فايكوتوباY \\
\hline 0 & 30.2 & 0 & 17.12 & 0 & 6.32 & 0 & 3.74 & المقارنة YY \\
\hline $9.7-$ & 27.25 & $21.3-$ & 13.46 & $26.2-$ & 4.66 & $15.7-$ & 3.15 & ملاثيون\س \\
\hline $25.6-$ & 22.45 & $40.7-$ & 10.14 & $34.65-$ & 4.13 & $20.5-$ & 2.97 & ملاثيون\ع \\
\hline $2.1-$ & 29.56 & $1.9-$ & 16.78 & $114.8+$ & 7.26 & $109+$ & 4.1 & تربلين \\
\hline $14.2-$ & 25.89 & 46- & 9.24 & $33.5-$ & 4.2 & $22.9-$ & 2.88 & تربلين\ع \\
\hline $0.01-$ & 30.1 & $101+$ & 17.3 & $25.1-$ & 4.73 & $41.1-$ & 2.2 & فايكوتوبل\س \\
\hline \multirow[t]{2}{*}{$6.7-$} & 28.17 & $29.1-$ & 12.13 & $61.5-$ & 2.43 & 42.2 & 2.16 & T14 فايكوتوب\ع T14 \\
\hline & 2.393 & & 1.489 & & 0.53 & & 0.169 & LSD $(0.05)$ \\
\hline
\end{tabular}




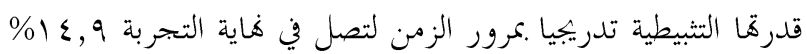

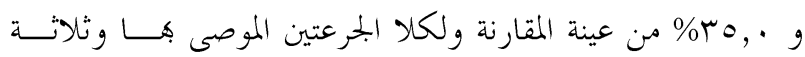

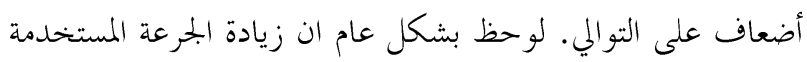

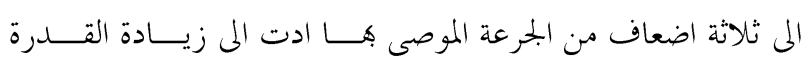
التثبيطية في عمل هذه المبيدات بالمقارنة مع عينة المقارنة. كما تبين من نتائج جدول(0) ان اضافة المادة العضوية لها تأثير في زيادة اعداد بكتريا التربة في عينات المقارنة (المعاملة T8 ) طوال جلمال فترة التجربة و كانت هذه الزيادة تدريجية وأستمرت اللى اليوم الأخير

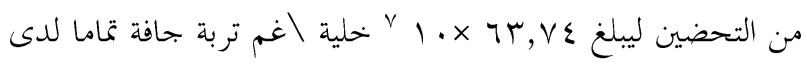

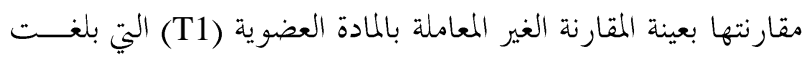

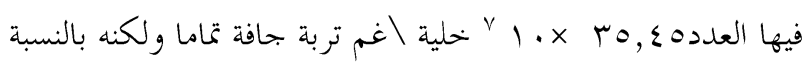

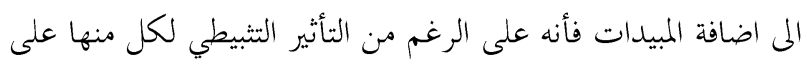

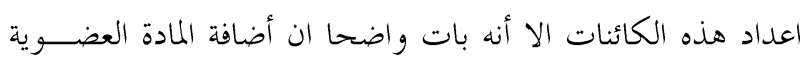

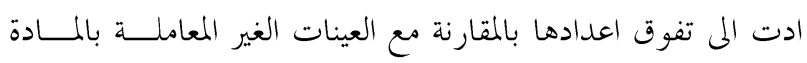

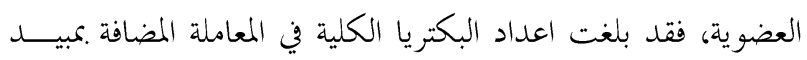
الملاثيون ولكلا الجرعتين الموصى هما وثلاثة أضعاف في العينات
ثانيا: تربة التون كوبري ا-1اعداد البكتريا الكلية:-

اوضحت النتائج المبينة في الجحدول(0) بأن الأعداد الكلية لبكتريا

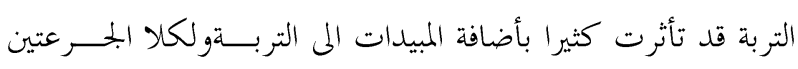
الموصى بها وثلاثة أضعاف، فقد ادت اضافة مبيد الملاثيون (المعاملتين

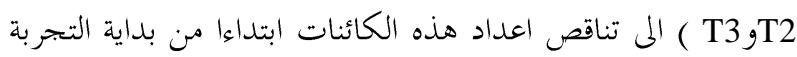

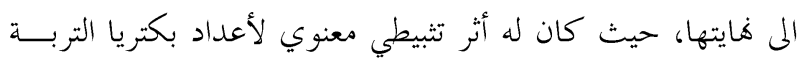

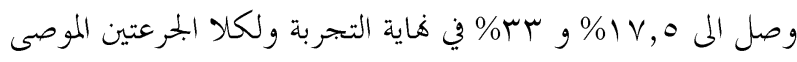

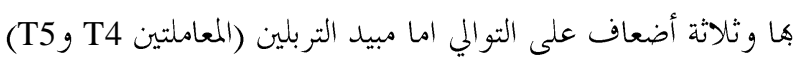

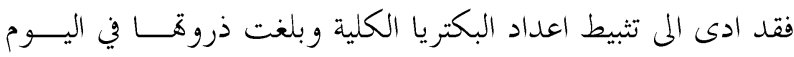

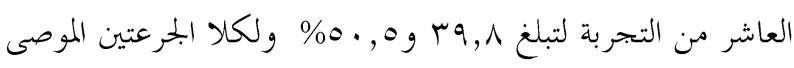
بها وثلائة أضعاف على التوالي. اما استخدام مبيد الفايكوتوب (المعاملتين T6 وT6) فأن تـأثيره

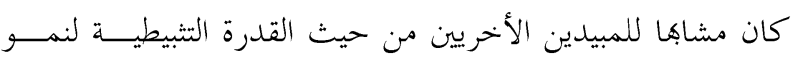

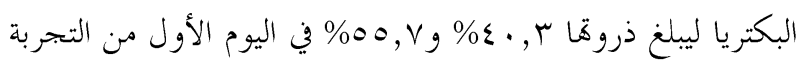

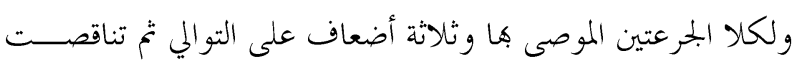

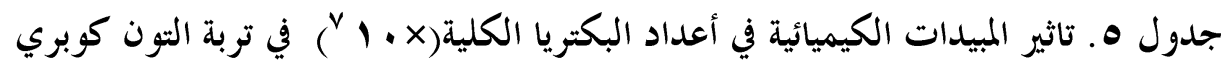

\begin{tabular}{|c|c|c|c|c|c|c|c|c|c|}
\hline أو الزيادة & وثلاثون & 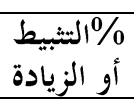 & و خشسة ون & 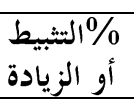 & عشرة ايام & أو التبيط ادة & يوم واحد & \multicolumn{2}{|c|}{ المعاملات } \\
\hline- & 30.45 & - & 24.96 & - & 10.6 & - & 7.12 & المقارنة|| & $\mathrm{T} 1$ \\
\hline $17.5-$ & 25.1 & $39.2-$ & 15.17 & $21.6-$ & 8.31 & $26.6-$ & 5.22 & ملاثيون \1 & $\mathrm{T} 2$ \\
\hline $33.0-$ & 20.4 & 46.7- & 13.28 & 54.5- & 4.82 & $45.2-$ & 3.9 & ملاثيون\ب & $\mathrm{T} 3$ \\
\hline $15.2-$ & 25.81 & $17.3-$ & 20.63 & $39.8-$ & 6.38 & $26.9-$ & 5.2 & تربلين \| & $\mathrm{T} 4$ \\
\hline $39.1-$ & 18.52 & $42.4-$ & 14.37 & $50.5-$ & 5.24 & $45.2-$ & 3.9 & تربلين & T5 \\
\hline 14.9- & 25.91 & $18.6-$ & 20.31 & $32.6-$ & 7.14 & 40.3- & 4.25 & فايكوتوب|| & T6 \\
\hline $35.0-$ & 19.78 & $39.3-$ & 15.15 & $39.2-$ & 6.44 & $55.7-$ & 3.15 & فايكوتوباب & $\mathrm{T} 7$ \\
\hline- & 63.74 & - & 55.12 & - & 17.16 & - & 8.52 & المقارنة Y & $\mathrm{T} 8$ \\
\hline $12.7-$ & 55.62 & $8.7-$ & 50.31 & 23.9- & 13.05 & $20.7-$ & 6.75 & ملاثيون\س & T9 \\
\hline 36.49- & 40.48 & $35.1-$ & 35.74 & 40.4- & 10.22 & $40.1-$ & 5.1 & ملاثيون\ع & $\mathrm{T} 10$ \\
\hline $17.5-$ & 52.54 & $3.3-$ & 53.25 & $7.7-$ & 15.83 & 18.4- & 6.95 & تربلين \ب & T11 \\
\hline $26.7-$ & 46.69 & $17.7-$ & 45.35 & $31.7-$ & 11.72 & 39.9- & 5.12 & تربلين & $\mathrm{T} 12$ \\
\hline $23.2-$ & 48.92 & 8.3- & 50.52 & $26.5-$ & 12.61 & $22.0-$ & 6.64 & فايكوتوب\\
س & $\mathrm{T} 13$ \\
\hline $31.8-$ & 43.42 & $27.1-$ & 40.13 & 21.9- & 13.39 & 49.4- & 4.31 & فايكوتوبل\ع & $\mathrm{T} 14$ \\
\hline & 5.071 & & & & 3 & & 0.461 & LSD & $.05)$ \\
\hline
\end{tabular}




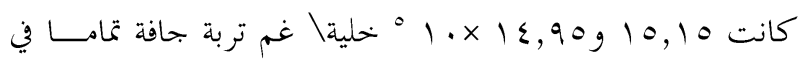

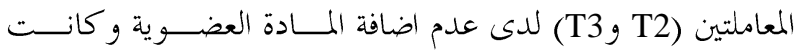
الفروقات غير معنوية بين الجرعتين. ما مبيد التربلين( المعاملتين T11 و T12) فكان تأثيره مشـــاهـا

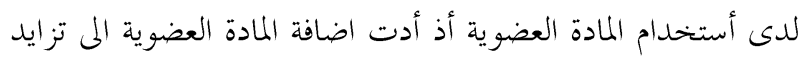
أعداد فطريات التربة على الرغم من أستخدام المبيد ولكلا الجرعتين

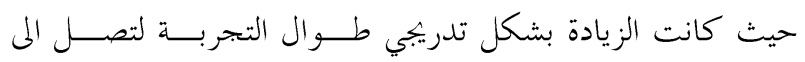

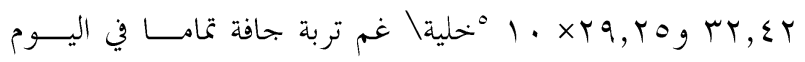

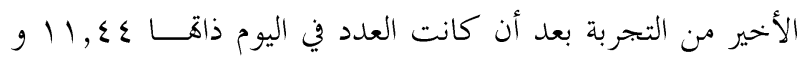

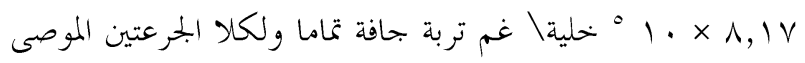

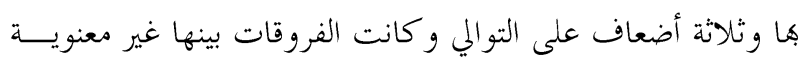

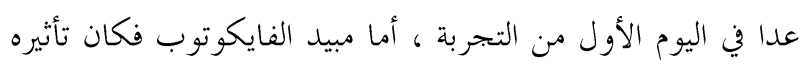

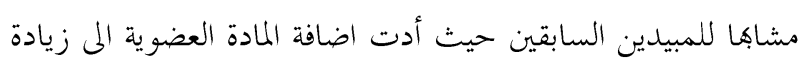

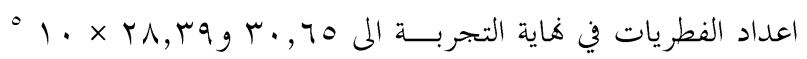

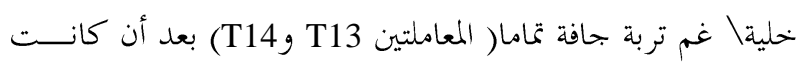

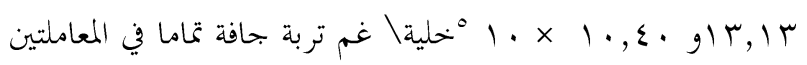

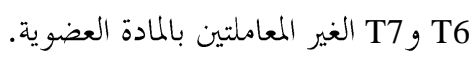

\section{ب- اعداد الأكتينو مايسيتات الكلية:}

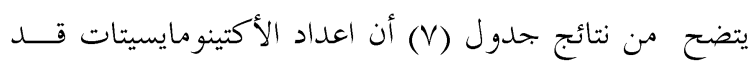
تأثرت بأضافة المبيدات الكيميائية لدى مقارنتها بالعينة الغير المعاملة

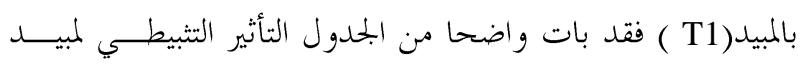

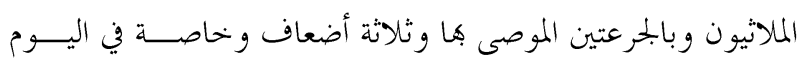

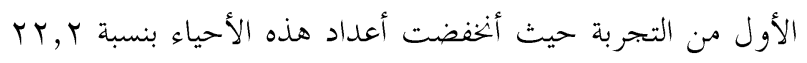

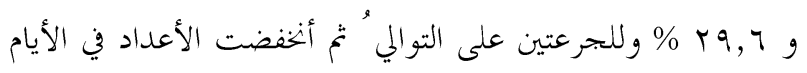

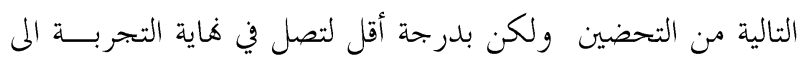

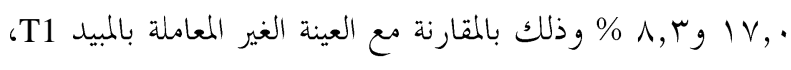

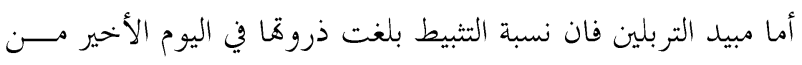

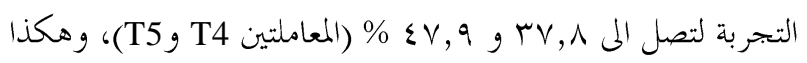

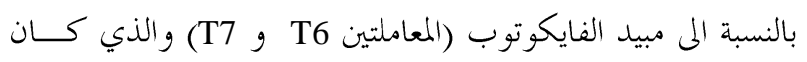

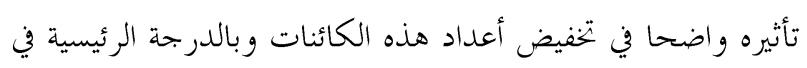

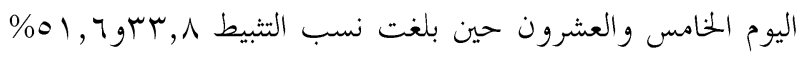

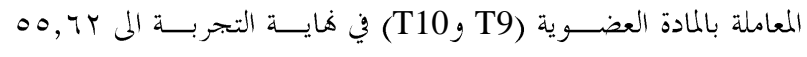

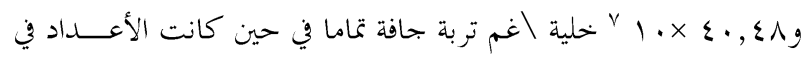

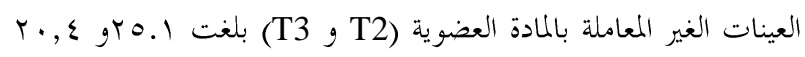

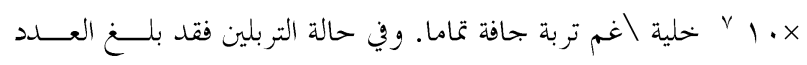

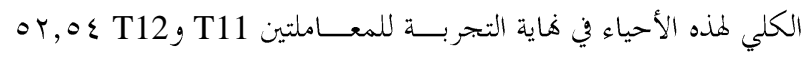

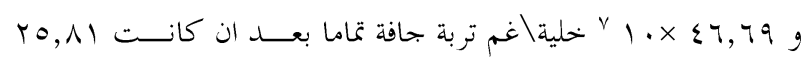

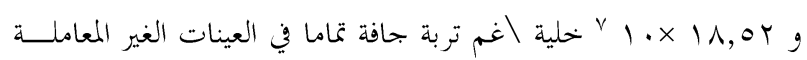

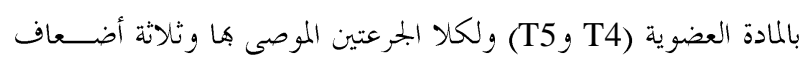

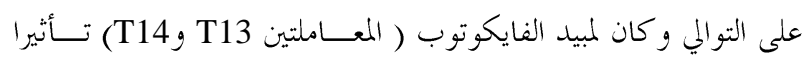

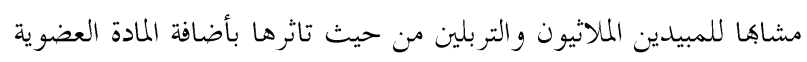

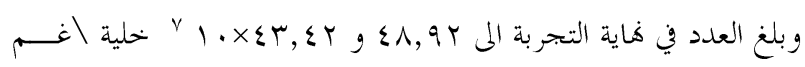

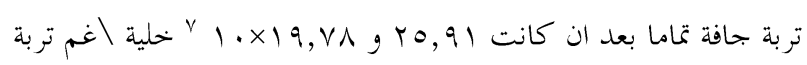
جافة تماما في المعاملتين T6 وT7 الغيرمعاملتين بالمادة العضوية. r-أعداد الفطريات الكلية:يظهر جدول (6) تأثير اضافة المبيدات الكيميائية على اعـــداد فطريات التربة، وقد تبين منه ان لأضافة مبيد الملاثيون تأثير تثبيطي

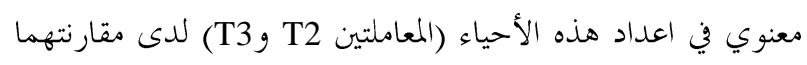

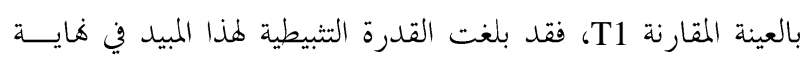

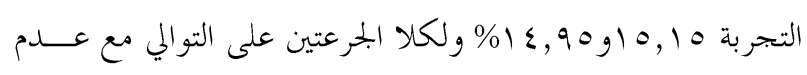

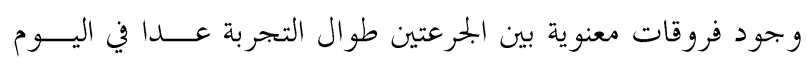

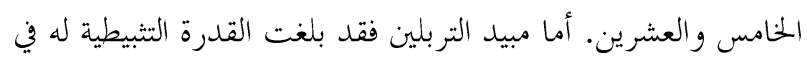

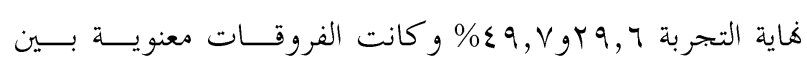

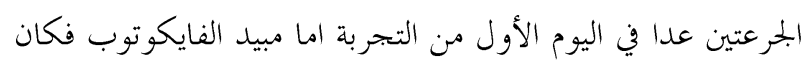

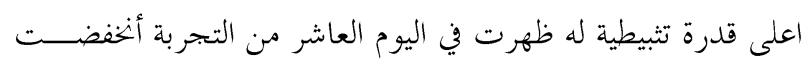

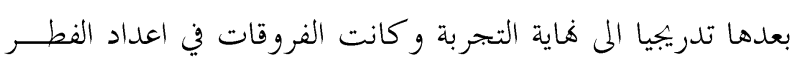
معنوية بين الجرعتين. كما دلت النتائج بأنه لدى مقارنة المعاملتين T8T1 فأن أضافة

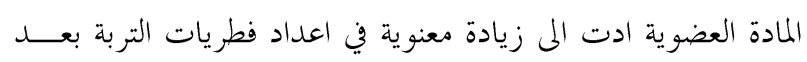

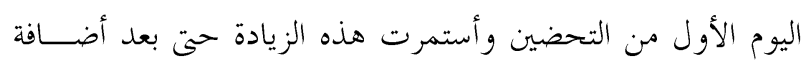
المبيدات فقد كانت الأعداد لدى أستخدام مبيد الملاثيون( المعاملتين

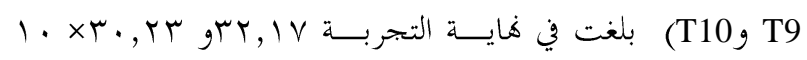

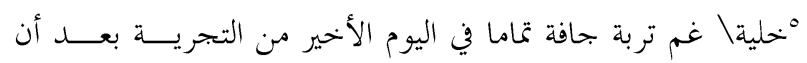


فقد تبين من أستخدام مبيد الملالثيون (المعـــاملتين T9 T10) ان

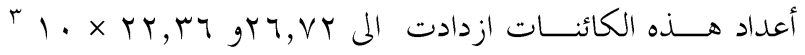
خليةلغم تربة جافة تماما بعد ان كانت العدد في المعاملات الغـير

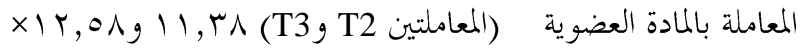

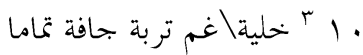

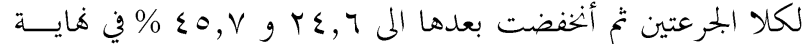
التجربة.

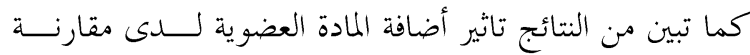
المعاملتين T1 و T8 مع بعضهما و لجميع فترات التحضين ليصل العلد

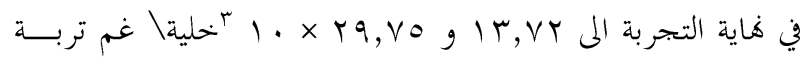
جافة تماما وأستمرت هذه الزيادة حتى بعد أستخدام المبيدات،

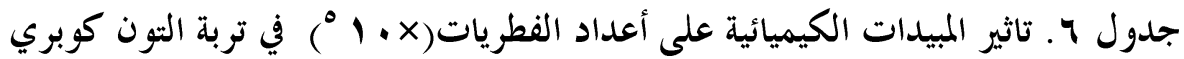

\begin{tabular}{|c|c|c|c|c|c|c|c|c|c|}
\hline أو الزيادة & وثلاثون & أو \%الزئبيط & وعشرون & 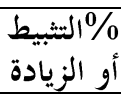 & عشرة & أو الزيادة التبيط & يوم واحد & \multicolumn{2}{|c|}{ المعاملات } \\
\hline- & 16.25 & - & 9.64 & - & 5.92 & - & 3.24 & المقارنة \1 & $\mathrm{T} 1$ \\
\hline $6.7-$ & 15.15 & $10.4-$ & 8.63 & $27.1-$ & 4.31 & 32.4- & 2.19 & ملاثيون \1 & $\mathrm{T} 2$ \\
\hline $8.0-$ & 14.95 & $16.7-$ & 8.03 & $36.4-$ & 3.76 & $32.0-$ & 2.2 & ملاثيون\Y & T3 \\
\hline $29.6-$ & 11.44 & $4.5-$ & 9.2 & $17.5-$ & 4.88 & $5.5-$ & 3.06 & تربلين | & $\mathrm{T} 4$ \\
\hline $49.7-$ & 8.17 & $21.9-$ & 7.52 & $33.1-$ & 3.96 & $14.8-$ & 2.76 & تربلين Y & T5 \\
\hline $19.2-$ & 13.13 & 29.1- & 6.83 & $44.4-$ & 3.29 & $12.0-$ & 2.85 & فايكوتوبال & T6 \\
\hline $36.0-$ & 10.4 & $44.5-$ & 5.35 & $51.0-$ & 2.9 & $30.2-$ & 2.26 & فايكوتوبا & T7 \\
\hline- & 35.24 & - & 21.13 & - & 7.23 & - & 3.66 & المقارنة\ب & T8 \\
\hline $8.7-$ & 32.17 & 9.3- & 19.16 & $12.0-$ & 6.36 & $16.3-$ & 3.06 & ملاثيون\ب & T9 \\
\hline $14.2-$ & 30.23 & $25.3-$ & 15.78 & 21.3- & 5.69 & 25.6- & 2.72 & ملاثيون\ع & $\mathrm{T} 10$ \\
\hline $8.0-$ & 32.42 & $13.2-$ & 18.34 & 9.8- & 5.14 & $9.2-$ & 3.32 & تربلين\س & $\mathrm{T} 11$ \\
\hline $16.9-$ & 29.25 & $42.2-$ & 12.2 & $39.8-$ & 4.35 & $12.5-$ & 3.2 & تربلين & T12 \\
\hline $13.0-$ & 30.65 & 12.1- & 18.57 & $30.5-$ & 5.02 & $15.8-$ & 3.08 & فايكوتوبلا & T13 \\
\hline \multirow[t]{2}{*}{ 19.4- } & 28.39 & $23.0-$ & 16.25 & $56.7-$ & 3.13 & $38.7-$ & 2.24 & فايكوتوب\\
ـ & $\mathrm{T} 14$ \\
\hline & 4.749 & & 0.424 & & 0.663 & & 0.478 & \multicolumn{2}{|c|}{ LSD 0.05} \\
\hline
\end{tabular}

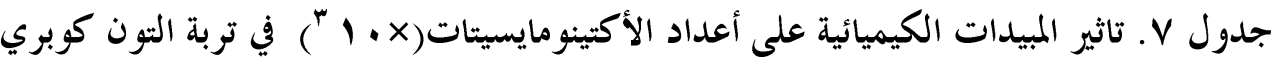

\begin{tabular}{|c|c|c|c|c|c|c|c|c|c|}
\hline أو الزيادة & وثلاثون & أو الزيادة & وعشرون & أو الزيادة & عشرة & النثيط \%ادة أو & واحد & \multicolumn{2}{|c|}{ المعاملات } \\
\hline- & 13.72 & - & 7.26 & - & 3.3 & - & 2.7 & المقارنة\| & $\mathrm{T} 1$ \\
\hline $17.0-$ & 11.38 & $12.1-$ & 6.38 & $15.7-$ & 2.78 & $22.2-$ & 2.1 & ملاثيون \1 & $\mathrm{T} 2$ \\
\hline $8.3-$ & 12.58 & $15.5-$ & 6.13 & $12.1-$ & 2.9 & $29.6-$ & 1.9 & مالثيون & T3 \\
\hline $37.8-$ & 8.53 & 8.6- & 6.63 & $5.7-$ & 3.11 & $21.1-$ & 2.13 & تربلين 1 & $\mathrm{~T} 4$ \\
\hline $47.9-$ & 7.14 & $20.2-$ & 5.79 & $6.0-$ & 3.1 & $22.9-$ & 2.08 & تربلين Y r & T5 \\
\hline $24.6-$ & 10.34 & $33.8-$ & 4.8 & 10.3- & 2.96 & $18.5-$ & 2.2 & فايكوتوبل| & T6 \\
\hline $45.7-$ & 7.44 & $51.6-$ & 3.51 & $36.0-$ & 2.11 & 57.4- & 1.15 & فايكوتوباب & $\mathrm{T} 7$ \\
\hline- & 29.75 & - & 18.26 & - & 5.12 & - & 3.87 & المقارنة ب & T8 \\
\hline $10.1-$ & 26.72 & $27.4-$ & 13.25 & 17.1 & 4.24 & $39.5-$ & 2.34 & ملاثيون\س & $\mathrm{T} 9$ \\
\hline $24.8-$ & 22.36 & $35.2-$ & 11.82 & $8.2-$ & 4.7 & $40.5-$ & 2.3 & ملاثيون\ع & $\mathrm{T} 10$ \\
\hline $15.5-$ & 25.13 & $26.2-$ & 13.46 & $24.4-$ & 3.87 & $40.0-$ & 2.32 & تربلين\س & $\mathrm{T} 11$ \\
\hline $25.3-$ & 22.2 & $49.9-$ & 9.14 & $39.2-$ & 3.11 & 53.4- & 1.8 & تربلين\ع & $\mathrm{T} 12$ \\
\hline $3.22-$ & 26.53 & 19.3- & 14.72 & $27.9-$ & 3.69 & 43.9- & 2.17 & فايكوتوبلاب & $\mathrm{T} 13$ \\
\hline $38.2-$ & 18.37 & 50.1- & 9.11 & $43.7-$ & 2.88 & $49.6-$ & 1.95 & فايكوتوبلى & T14 \\
\hline & 1.405 & & 1.615 & & 0.283 & & 2.046 & LSD $(0$ & \\
\hline
\end{tabular}


يتضح من النتائج السابقة أن تأثيرالمبيدات الكيميائية على بحتمع

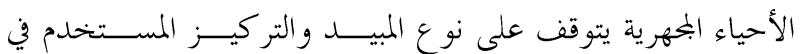
المكافحة ومدة استمرار فاعليته، لذا فأنه بالنسبة الى المبيدات الأكثر

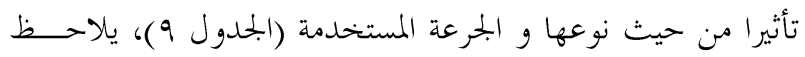

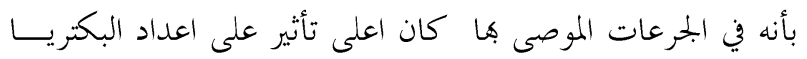

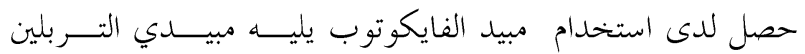

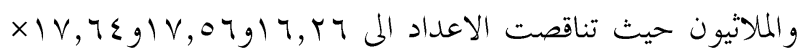

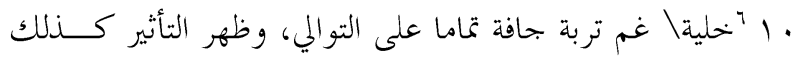

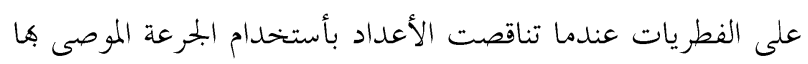

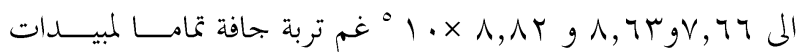
الفايكوتوب والملاثيون و التربلين على التو الي. اما الأكتينومايسيتات

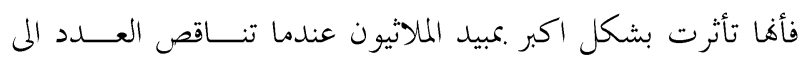

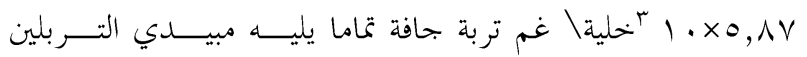

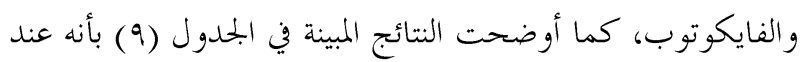

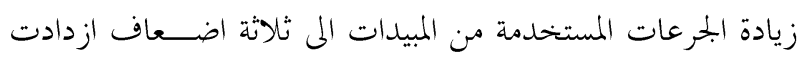

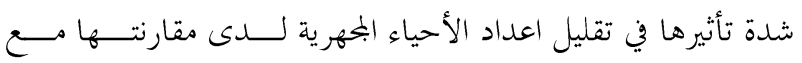

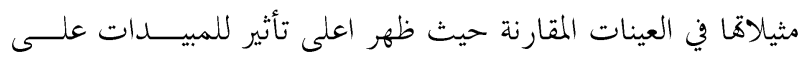

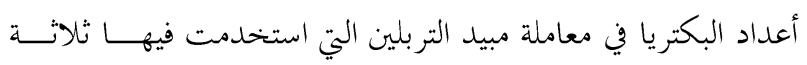

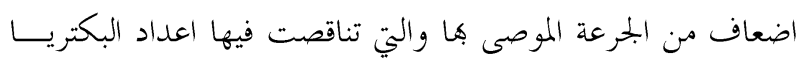

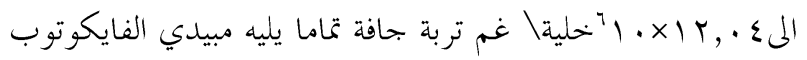

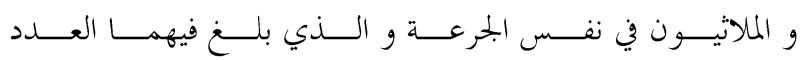

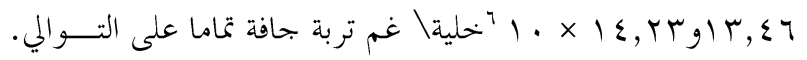

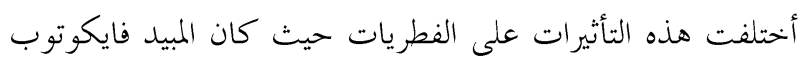
اكثر تأثيرا في خفض اعداد الفطريات يليه مبيدي التربلين والملاثيون

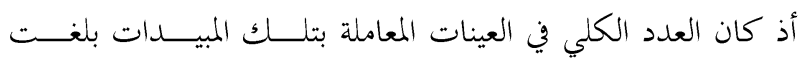

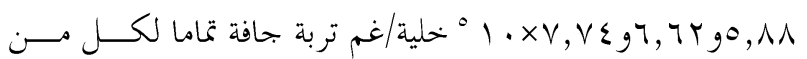
المبيدات الثلاثة على التو الي.

وتشاهت هذه المبيدات في تأثيراتا على اعداد الأكتينومايسيتات

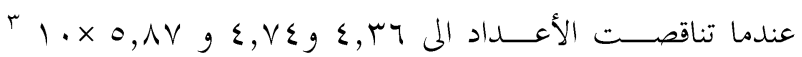
خلية/غم تربة جافة تماما للمبيدات المذكورة على التوالي.
وهكذا بالنسبة المى مبيد التربلين حيث بلغ العدد في المعــاملتين

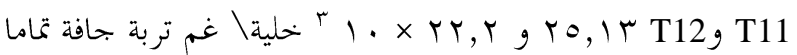

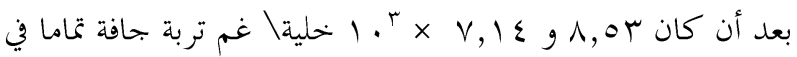
المعاملتين T4 وT5 الغير المعاملين بالمادة العضوية. ويبدو الأمر مشاها مع المبيد فايكوتوب حيث بلغت الأعداد في

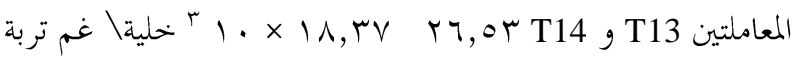
جافة تماما في حين كانت هذه الأعداد في العينة الغير المعاملة بالمادة

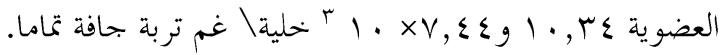
يتضح من النتائج السابقة ان اضافة المادة العضوية قــــ أدت في

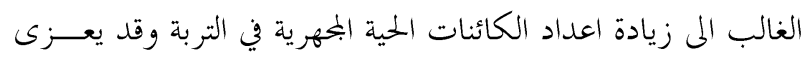
ذلك الى التقليل من فعالية المبيد من خلال ادمصاصه على السطوح

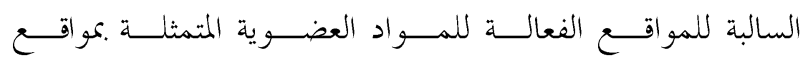

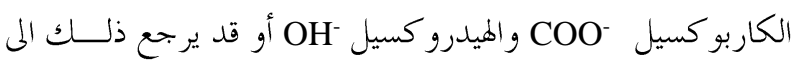

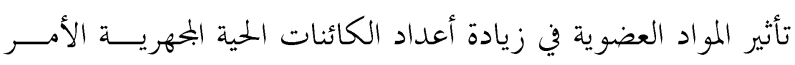

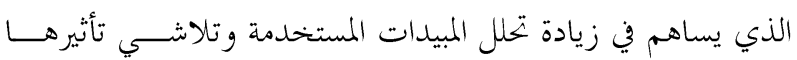

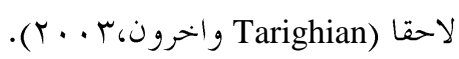
لدراسة تأثير أختلاف التربتين وأهمية أحتوائهما مـــن المـادة العضوية في أعداد الأحياء المجهريةفي التربة ،تمت مقارنــــة التــــتبتين

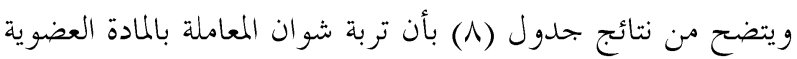

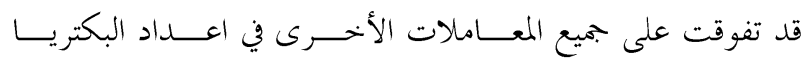

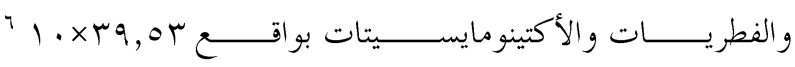

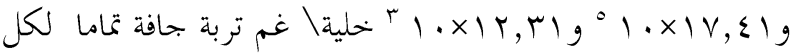

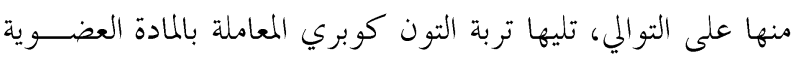

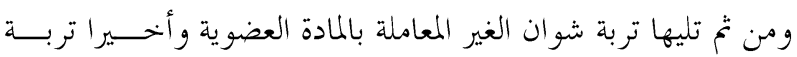

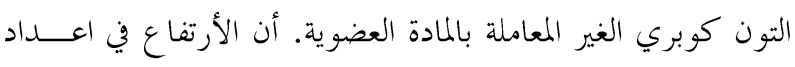

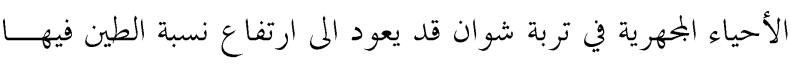

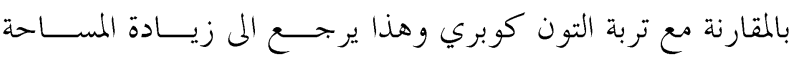

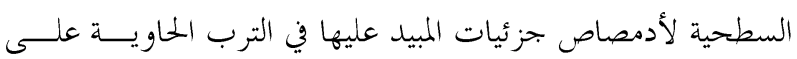

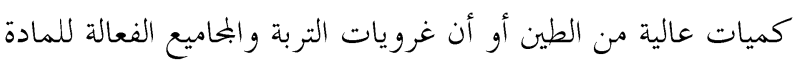
العضوية تقومان بأدمصاص او التحليل المائي لبعض هذه المركبات

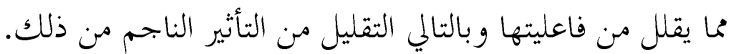


جدول ^. أعداد الكائنات الحية الجهرية وفق أختلاف التربة والمادة العضوية أعداد الكائنات الحية الجهرية في التربة العمدية

\begin{tabular}{|c|c|c|c|}
\hline \multicolumn{3}{|c|}{ أعداد الكائنات الحية الخهرية في التربة } & \multirow[t]{2}{*}{ المعاملات } \\
\hline 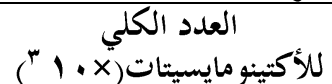 & 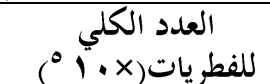 & 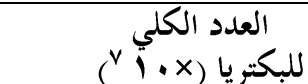 & \\
\hline $0, r_{1}$ & $\mathrm{~T}, \wedge \mathrm{V}$ & ITGTV & تربة التون كوبري بدون المادة العضوية \\
\hline $1 \cdot, 9$. & $|\varepsilon, r|$ & $r 9, r_{4}$ & تربة التون كوبري مضاف اليه المادة العضوية \\
\hline 7,19 & $9, \cdot$ & $1 \mathrm{~A}, \mathrm{VT}$ & تربة شوان بدون المادة العضوية \\
\hline$|r, r|$ & $|V, \Sigma|$ & r960r & تربة شوان مضاف اليه المادة العضوية \\
\hline \multicolumn{4}{|c|}{ جدول 9.} \\
\hline \multicolumn{3}{|c|}{ أعداد الكائنات الحية الجهرية في التربة } & \multirow[t]{2}{*}{ المعاملة } \\
\hline 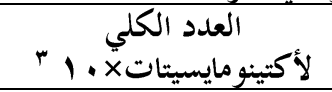 & 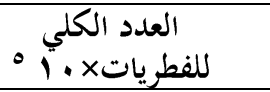 & للبكتريا × ألب ن & \\
\hline$V, r \varepsilon$ & $1 \cdot, 1 \wedge$ & $r \cdot, \Lambda r$ & المقارنة( بدون أضافة المادة العضوية) \\
\hline$\bullet, \Lambda \mathrm{V}$ & 1, ז & $I V, T \varepsilon$ & ملاثيون (الجرعة الموصى فيا) \\
\hline $0, V_{4}$ & $v, V \varepsilon$ & $1 \varepsilon, r^{\pi}$ & ملاثيون(ثلاثة أضعاف من الجرعة الموصى هـا) \\
\hline $7, .1$ & $\Lambda, \Lambda T$ & $1 \mathrm{~V}, 04$ & تربلين(الجرعة الموصى هـا) \\
\hline$\varepsilon, V \varepsilon$ & $7, \pi$ & $1 Y, \cdot \varepsilon$ & تربلين(ثلاثة أضعاف من الجرعة الموصى فـا) \\
\hline 7, ז & $v, 74$ & 17,14 & 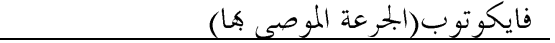 \\
\hline$\varepsilon, \mu_{4}$ & $0, \wedge \wedge$ & & فايكوتوب(ثلاثة أضعاف من الجرعة الموصى هيا) \\
\hline
\end{tabular}

\begin{tabular}{|c|c|c|c|}
\hline \multicolumn{3}{|c|}{ أعداد الكائنات الحية الجهرية في التربة } & \multirow[t]{2}{*}{ 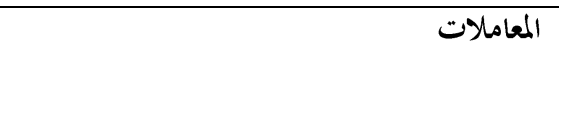 } \\
\hline 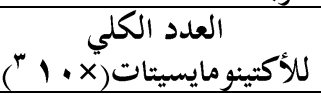 & للفطريات(×دملي ه) & 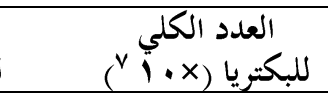 & \\
\hline $0, r$ & $\neg, \wedge \mathrm{V}$ & Ir.TV & تربة التون كوبري بدون المادة العضوية \\
\hline $1 \cdot, 9$. & $|\varepsilon, Y|$ & $r q, Y Y$ & تربة التون كو بري مضاف اليه المادة العضوية \\
\hline $7, Y 9$ & $9, \cdot$ & $1 \Lambda, V T$ & تربة شوان بدون المادة العضوية \\
\hline$|r, \mu|$ & $|V, \varepsilon|$ & r9,or & تربة شوان مضاف اليه المادة العضوية \\
\hline \multicolumn{4}{|c|}{ جدول 9. يبين أعداد الكائنات الحية البجهرية قبل المعاملة بالمادة العضوية } \\
\hline \multicolumn{3}{|c|}{ أعداد الكائنات الحية البجهرية في التربة } & \multirow[t]{2}{*}{ المعاملة } \\
\hline 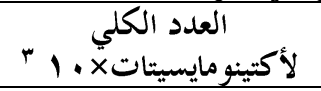 & للفطريات الكلي ـ العدد & للبكتريا× • آلعلي & \\
\hline$V, r \varepsilon$ & $1 \cdot, 11$ & $r \cdot, \Lambda r$ & المقارنة (بدون أضافة المادة العضوية) \\
\hline $0, \wedge \vee$ & A, & $1 V, T \varepsilon$ & ملاثيون(الجرعة الموصى هـا) \\
\hline $0, V T$ & $\vee, \vee \leqslant$ & $1 \varepsilon, Y T$ & ملاثيون(ثلاثة أضعاف من الجرعة الموصى بها) \\
\hline $7, \cdot 1$ & $\Lambda, \wedge \mathrm{r}$ & $1 \mathrm{~V}, 07$ & تر بلين(الجرعة الموصى فما) \\
\hline$\varepsilon, V \varepsilon$ & $7,7 T$ & IT,,$\varepsilon$ & تربلين(ثلاثة أضعاف من الجرعة الموصى هـا) \\
\hline T,r & $V, T T$ & $17, Y 7$ & فايكوتوب(الجرعة الموصى هـا) \\
\hline$\varepsilon, r \uparrow$ & $0, \wedge \Lambda$ & $1 \mu, \Sigma 7$ & فايكوتوب(ثلاثة أضعاف من الجرعة الموصى هـا) \\
\hline
\end{tabular}
المعاملات

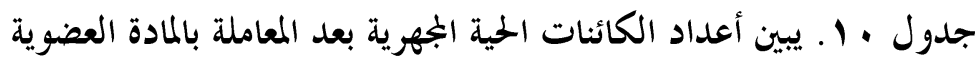

\begin{tabular}{|c|c|c|c|}
\hline \multicolumn{3}{|c|}{ أعداد الكائنات الحية الجهيرية في التربة } & \multirow[b]{2}{*}{ 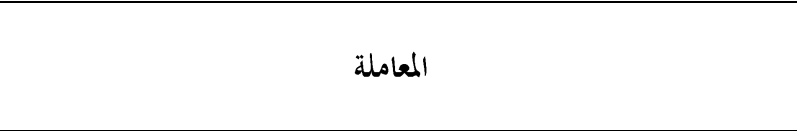 } \\
\hline 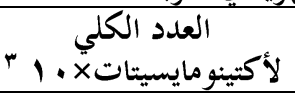 & 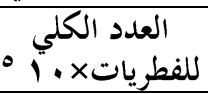 & للبكتريا× •إملي & \\
\hline $1 \varepsilon, \Gamma$ & $19, .9$ & $\varepsilon r, \varepsilon r$ & المقارنة(مضاف اليه المادة العضوية) \\
\hline $11, \wedge \wedge$ & IV,TY & $r \wedge, r \mid$ & ملاثيون (الجرعة الموصى بها مضاف اليه المادة العضوية) \\
\hline $1 \cdot, 11$ & $1 \leqslant, 07$ & $r \cdot, r_{q}$ & ملاثيون (ثلاثة أضعاف من الجرعة الموصى بكا مضاف اليه المادة العضوية) \\
\hline$|r, \Lambda|$ & IV,,$r$ & rV, rA & تربلين( الجرعة الموصى هجا مضاف اليه المادة العضوية) \\
\hline $9, \wedge 1$ & 1r, & $r \cdot, r_{0}$ & تربلين(ثلاثة أضعاف من الجرعة الموصى هما مضاف اليه المادة العضوية) \\
\hline$M, T \Lambda$ & $10, r \varepsilon$ & r,$\wedge 9$ & فايكوتوب( الجرعة الموصى جها مضاف اليه المادة العضوية) \\
\hline 9,70 & $1 \varepsilon, \ldots$ & rV, $\Sigma T$ & فايكوتوب(ثلاثة أضعاف من الجرعة الموصى هـا مضـــاف اليـــه المـــادر \\
\hline
\end{tabular}

\begin{tabular}{|c|c|c|c|}
\hline \multicolumn{4}{|c|}{ جدول 1 ا ـ يبين أعداد الكائنات الحية الججرية وفق أختلاف فترات التحضين } \\
\hline \multicolumn{3}{|c|}{ أعداد الكائنات الحية البجهرية في التربة } & \multirow{2}{*}{ فترات التحضين (الأيام) } \\
\hline العدد الكلى لأكتينو مايسيتات × ، " & العدد الكلى للفطريات×× 1 1. & 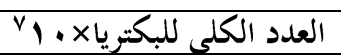 & \\
\hline$r, \varepsilon q$ & $r, r$. & $\Upsilon, \Sigma$ & يوم واحد \\
\hline$\varepsilon, \cdot 1$ & $0, \Sigma Y$ & $1 T, \cdot 9$ & . أيام. \\
\hline 9,10 & $|r, \Lambda|$ & $\varepsilon 0, .0$ & مب بوم \\
\hline $11,0 r$ & $r \leqslant, q \leqslant$ & $\varepsilon \vee, \varepsilon 1$ & مبوم \\
\hline
\end{tabular}

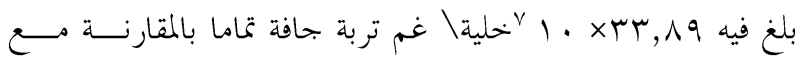

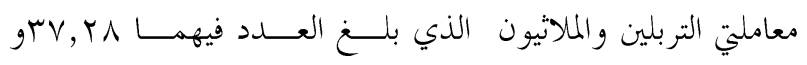

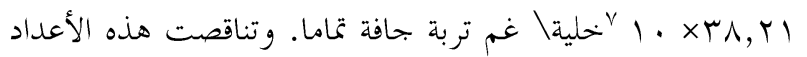

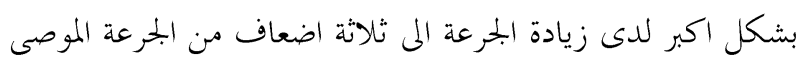

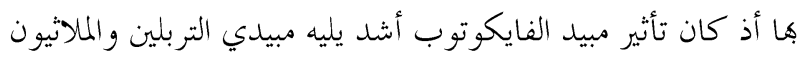

دلت النتائج في جدول(· • (1) بأن اضافة المادة العضوية الم التربة

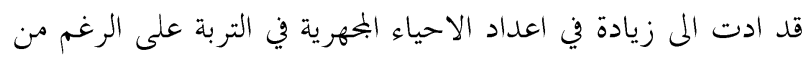

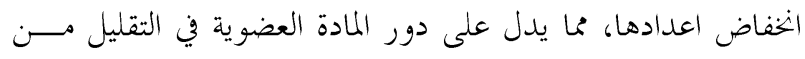

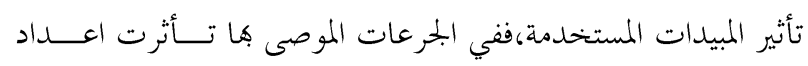

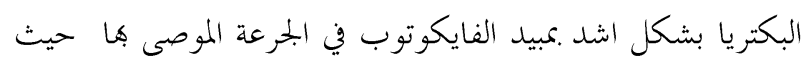


Ahtiainena, J. H., P. Vanhala and A. Myllymäkib.2003. Effects of different plant protection programs on soil microbes. Ecotoxicology and Environmental Safety, Volume 54, Issue 1 , January 2003, Pages 56-64.

Das, A. C. and Mukherjee, D. (2000). Soil application of insecticides influences microorganisms and plant nutrients. Applied Soil Ecology, 14: 55-62.

EL-Shahawy, R.M., Amer, H.A. and Ayed, I.A. (1986). Effect of three commonly used pesticides on some groups of microorganisms and their activities in soil. J. Coll. Agric., King Saud Univ., 8 : 457-470.

Osman, A. G., V.A. Kalinin, V. T. Emtsev, and K.V. Bikov .1999. Effect of new broad spectrum fungicide Amistar on soil microorganisms in field conditions.(from internet).

Park, J-H.; Feng, Y.; Ji, P.; Voice, T.C. and Boyd, S.A. (2003). Assessment of bioavailability of soil-sorbed atrazine. Applied and Environmental Microbiology, 69: 3288-3298.

Singh, B.K.; Walker, A.; Morgan, J.A.W. and Wright, D.J. (2004). Biodegradation of chlorpyrifos by Enterobacter strain B-14 and its use in bioremediation of contaminated soils. Applied and Environmental Microbiology, 70: 4855-4863.

Taiwo L. B and Oso B. A. (1997).The influence of some pesticides on soil microbial flora in relation to changes in nutrient level, rock phosphate solubilization and $\mathrm{P}$ release under laboratory conditions . Agriculture, ecosystems \& environment Vol. 65 No.1:59-68

Tarighian, A.; Hill, G.; Headley, J. and Pedras, S. (2003). Enhancement of 4-chlorophenol biodegradation using glucose. Clean Technologies and Environmental Policy, 5: 61-65.

Sláviková, E., Vadkertiová, ToppR.2003. Effects of pesticides on yeasts isolated from agricultural soil. Z. Naturforschung, 58c, 855- 859 (2003).

De Lorenzo, D'ovidio R.and F. Cervone. 2001. The role of polygalacturonase-inhibiting proteins (PGIPs) in defence against pathogenic fungi. Annu. Rev. Phytopathol. 39: 313-335.

Mark E. Hines, Patrick M. Crill, Ruth K. Varner, Robert W. Talbot, Joanne H. Shorter, Charles E. Kolb, and Robert C. Harriss.(1998).Rapid Consumption of Low Concentrations of Methyl Bromide by Soil Bacteria .App 1. Environ. Microbiol.vol:64 no. 5 1864-1870.

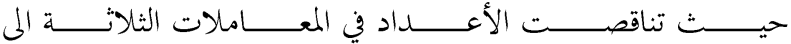

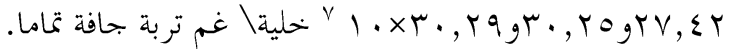

$$
\begin{aligned}
& \text { في حالة الفطريات و الأكتينومايسيتات فكان التأثير مشـــابها المى } \\
& \text { البكتريا من حيث نوع المبيد وجرعته ،حيث نلاحظ بــأن تــأثير } \\
& \text { الفايكوتوب اكثر في خفض الأعداد ولكلا الجرعتين يليه مبيــــي } \\
& \text { التربلين و الفايكوتوب. ان التأثنير الأكثر لمبيد الفايكوتوب قد يعــود } \\
& \text { الى اضافة المبيدات الفطرية معدلات عالية محا يؤثر تأثيرا مثبطا على } \\
& \text { الأحياء البحهرية التي تتعرض لهذه التركيزات وعلى العكس من ذلك }
\end{aligned}
$$

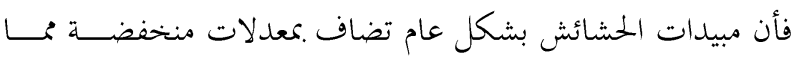

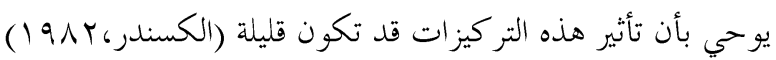

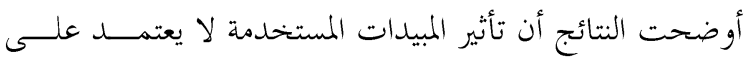

$$
\begin{aligned}
& \text { نوعية المبيد و الأحياء البمهرية فحسب بل يعتمد ايضا على فتـــرات } \\
& \text { التحضين حيث أظهرت النتائج الموضحة في الجدول(1 (1) بأن اعلى }
\end{aligned}
$$

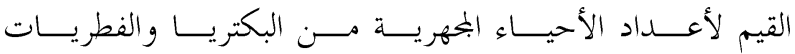

$$
\begin{aligned}
& \text { و الأكتينومايسيتات ظهرت في اليوم الخامس والثالثون من التحضين }
\end{aligned}
$$

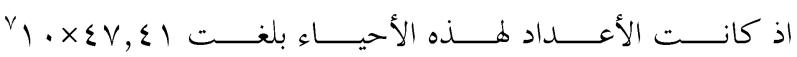

$$
\begin{aligned}
& \text { و \& } \\
& \text { منها على التوالي تلي بعدها فتـــرات التحضـــن للأيسـام الخــــامس } \\
& \text { و العشرون و العاشر و اليوم الأول على التوالي. }
\end{aligned}
$$

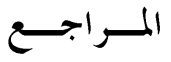

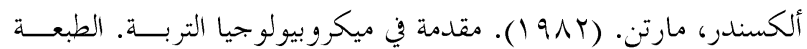

$$
\begin{aligned}
& \text { الثانية. جون و ايلي وأو لاده- نيويوك }
\end{aligned}
$$

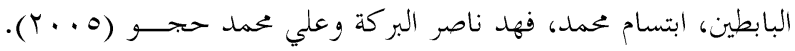

$$
\begin{aligned}
& \text { تأثير مبيدي اللانيت والديازينون على بعض الأحياء الدقيقة في التربة } \\
& \text { في و جود المادة العضوية. موقع على الشبكة المعلوماتية(الأنترنيت). }
\end{aligned}
$$

ABSTRACT Effect of Some Pesticides on Soil Microorganisms in Soil of Kirkuk Province 


$$
\text { دلشاد رسول عزيز: تأثير بعض المبيدات الكيميائية المستخدمة لمكافحة الافات الزراعية على أعداد الإحياء المخهرية في التربة بمحافظة كركوك| العراق }
$$

\title{
2-Reduction of Pesticides Effect on Soil Microorganisms by Addition of Organic Matter under Laboratory Conditions
}

\author{
Delshad Rassul Aziz
}

The widespread used of pesticides during agricultural service caused soil pollution by toxic chemicals found in these compounds in the soils, affecting on soil microorganisms, changing their numbers. Also heated matter affects the period of maintain of these pollutants in soils whereas the pesticide mobility depends on its reacting with soil particles and soil organic matter according to adsorption and desorption.

The objectives of this work were to study the effect of pesticides on the soil microbial and reduction of ecosystem pollution by addition of organic matter, for that, laboratory experiment was conducted to valence the pesticide addition effect on soil microbial numbers and possibility of reduction of there effects by organic matter supplying in Kirkuk province. So two soils were chosen in Shwan and Alton -Kopri, soil samples were air dried, sieved throw $2 \mathrm{~mm}$ sieve. Hundred gms of soil were taken in plastic dishes, treated with insecticides, herbicides and fungicide includes malathion, tripline and phycotop respectively in recommended and three times more than recommended doses, $1 \%$ organic matter (Liqhumus 18\%) was added to reduce pesticides effects ,then the soils incubated at $28-^{+} 2 \mathrm{C}^{\circ}$ and moisture humidity maintain at $70 \%$ of field capacity, Soil samples were taken periodically after $1,10,25$ and 35days to estimate total bacterial colony, fungus and actinomycetes.
The obtained result indicated that the soil microorganisms have important roles for studying pesticides side-effects, whereas these pesticides, generally, reduce soil microbial numbers. In recommended dosages, the greatest effect on soil bacteria occurred by phycotop treatment followed by tripline and malathion, but actinomycetes were more affected by malathion. In three times more than recommended treatment, tripline was more effective on bacteria followed by phycotop and malathion, but phycotop was more inhibitor for fungus and actinomycetes.

The results also indicated that organic matter reduces inhibition effects of used pesticides in both soils. Shwan soil treated by organic matter exceed on all other treatments in all soil microbial numbers, followed by Alton-Kopri treated by organic matter and then Shwan and Alton-Kopri un treated soils. The obtained data showed that all used pesticides have toxic effect on soil microorganisms with differences caused by there maintain in soil and dosage concentration.Data showed that the greatest number of soil microorganisms occurred at the $35^{\text {th }}$ day of the experiment.

Keywords: pesticides, soil microorganisms, organic matter 